TI 2011-080/2

Tinbergen Institute Discussion Paper

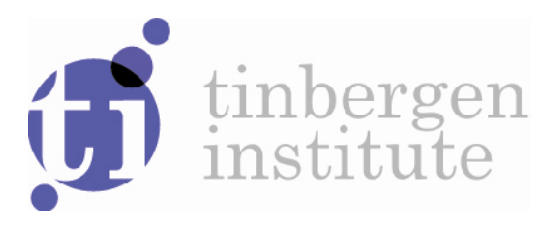

\title{
From First-Release to Ex-Post Fiscal Data: Exploring the Sources of Revision Errors in the EU
}

Roel Beetsmal

Benjamin Bluhm²

Massimo Giuliodori

Peter Wierts 3

\footnotetext{
${ }^{1}$ Faculty of Economics and Business, University of Amserdam, Dept. of Economics, and Tinbergen Institute;

2 Graduate School of Economics, Finance and Management, Goethe University Frankfurt;

${ }^{3}$ Economics and Research Dept., De Nederlandsche Bank, Amsterdam.
} 
Tinbergen Institute is the graduate school and research institute in economics of Erasmus University Rotterdam, the University of Amsterdam and VU University Amsterdam.

More TI discussion papers can be downloaded at http://www.tinbergen.nl

Tinbergen Institute has two locations:

Tinbergen Institute Amsterdam

Gustav Mahlerplein 117

1082 MS Amsterdam

The Netherlands

Tel.: +31(0)205251600

Tinbergen Institute Rotterdam

Burg. Oudlaan 50

3062 PA Rotterdam

The Netherlands

Tel.: +31(0)10 4088900

Fax: +31(0)104089031

Duisenberg school of finance is a collaboration of the Dutch financial sector and universities, with the ambition to support innovative research and offer top quality academic education in core areas of finance.

DSF research papers can be downloaded at: http://www.dsf.nl/

Duisenberg school of finance

Gustav Mahlerplein 117

1082 MS Amsterdam

The Netherlands

Tel.: +31(0)20 5258579 


\title{
From First-Release to Ex-Post Fiscal Data: Exploring the Sources of Revision Errors in the EU*
}

\author{
Roel Beetsma, ${ }^{\dagger}$ Benjamin Bluhm, $^{\ddagger}$ Massimo Giuliodori $^{\S}$ and Peter Wierts ${ }^{* *}$
}

\begin{abstract}
This paper explores the determinants of deviations of ex-post budget outcomes from firstrelease outcomes published towards the end of the year of budget implementation. The predictive content of the first-release outcomes is important, because these figures are an input for the next budget and the fiscal surveillance process. Deviations of ex-post from firstrelease fiscal figures may arise for political and strategic reasons. In particular, Ministries of Finance control the production of first-release figures, and may have an incentive to be overoptimistic at this stage. Our results suggest that an improvement in the quality of institutions, whether measured by the tightness of national fiscal rules, the medium-term budgetary framework or budgetary transparency, reduces the degree of optimism at the first-release stage, thereby making first-release figures more informative about the eventual outcomes. This supports the European Commission proposals for minimum standards for national fiscal frameworks and amendments by the European Parliament for improving national ownership. It also strengthens the case for a close monitoring by the Commission of the first-release production of fiscal figures.
\end{abstract}

This version: May 2011.

JEL codes: E6, H6.

Keywords: real-time data, first-release data, ex-post data, fiscal policy, biases, decomposition, base effect, growth effect, denominator effect, fiscal institutions.

\footnotetext{
* We thank Geert Langenus and Walpurga Koehler-Toeglhofer for their help in explaining large one-off data reclassifications for Belgium and Austria. We thank for helpful comments participants at the conference "PostCrisis Fiscal Consolidation Strategies for Europe" (University of Freiburg) and the $13^{\text {th }}$ Banca d'Italia Public Finance Workshop (Perugia) and at seminars at the University of Aarhus and the University of Oslo. The usual disclaimer applies.

${ }^{\dagger}$ Corresponding author. Address: Department of Economics, University of Amsterdam, Valckenierstraat 65-67, 1018 XE Amsterdam, The Netherlands; phone: +31.20.5255280; fax: +31.20.5254254; e-mail: r.m.w.j.beetsma@uva.nl.

‡ Address: Graduate School of Economics, Finance and Management, Goethe University Frankfurt, Grüneburgplatz 1 (House of Finance), 60323 Frankfurt, Germany, email: benjamin.bluhm@hof.uni-frankfurt.de.

$\S$ Address: Department of Economics, University of Amsterdam, Valckenierstraat 65-67, 1018 XE Amsterdam, The Netherlands; phone: +31.20.5254011; fax: +31.20.5254254; e-mail: m.giuliodori@uva.nl.

** Address: Economics and Research Department, De Nederlandsche Bank, Westeinde 1, 1017 ZN Amsterdam, The Netherlands; phone: +31.20.5245827; e-mail: peter.wierts@dnb.nl.
} 


\section{Introduction}

The budget process consists of three stages. The first stage is the planning stage, ${ }^{1}$ while the second stage is the implementation stage, which leads to the real-time "first-release" outcomes published towards the end of the year of implementation. Finally, the ex-post control stage produces the "revised" or "ex-post" outcomes. These outcomes measure the budgetary situation of a given year most accurately, because they are based on the largest available amount of information and (in the EU) are published by the national statistical office after having been scrutinised by Eurostat. First-release outcomes generally differ from the originally planned or projected values, for example because of unexpected economic events during the implementation stage, discretionary measures taken in response to those events or because policymakers choose to deliberately bias their projections. The result is an implementation error. Also ex-post outcomes often differ from first-release outcomes, giving rise to a revision error, for example because of data revisions and the fact that first-release figures are constructed before the end of the fiscal year. In addition, governments may have political or strategic motives to affect the first-release figures. The growing literature exploring fiscal slippages in the EU has largely neglected the different stages at which slippages take place. ${ }^{2}$ This is an important omission, because the sources of the slippages at the various stages differ and, hence, may require different institutional measures to deal with them.

Beetsma et al. (2009) extensively explore the determinants of both budgetary plans and the first-release deviations from those plans using data from the EU Stability and Convergence Programs over the period 1998-2008. These programs constitute a harmonised source of data on fiscal plans and outcomes in EU countries. The authors show that fiscal slippages can be mainly attributed to the spending side of the budget. Moreover, they find that economic rather than political factors are major determinants of both stages of the budgetary process. National fiscal rules and medium-term budgetary frameworks also affect the

\footnotetext{
${ }^{1}$ The planning stage can be further divided into a stage in which the government constructs the budget and a parliamentary approval stage.

${ }^{2}$ Use of real-time data for fiscal policy analysis has become quite popular recently, an advantage of real-time data being that such data capture more accurately (than ex-post data) the information set of the policymakers at the moment they take their decisions. These decisions comprise both the fiscal plan and its implementation. See, for example, Forni and Momigliano (2004), Cimadomo (2007), Marinheiro (2008), Bernoth et al. (2008), Lewis (2009) and Pina (2009). An early contribution is Strauch et al. (2004), who use data on budget balances from the stability and convergence programmes over the period 1991-2002 and find that governments on average predict the future budget outcome fairly well. Brück and Stephan (2006) and Pina and Venes (2011) investigate the political determinants of forecast errors in fiscal policy, while controlling for economic variables.
} 
ambition of fiscal plans as well as the degree of adherence to those plans. The importance of the tightness of national fiscal rules is confirmed in work by Abbas et al. (2011), who focus on large adjustment plans over a three-year horizon in the EU initiated in the period 19912005, and by Holm-Hadulla et al. (2011), who show that tighter expenditure rules in the EU limit deviations of actual from planned discretionary spending in response to positive output gap surprises.

In this paper, again using the data from the EU Stability and Convergence Programs we will explore the determinants of the deviations of ex-post budget outcomes from the firstrelease outcomes. A systematic analysis of revision biases has been rarely done in the literature, ${ }^{3}$ but is relevant for several reasons. First, an assessment of the predictive content of first-release for ex-post outcomes is important, because first-release outcomes are used for fiscal surveillance and could give rise to policy adjustments. In particular, first-release data may send an early signal of a lack of fiscal sustainability, in which case a tightening of planned fiscal policy could be warranted. Second, because first-release data provide an estimate of the current budgetary situation, they form the basis for the evaluation of the budget implementation for the current year and they are an input into the formulation of the new budget. ${ }^{4}$ First-release figures are closest to the information set available to policymakers when they implement their policies and so are most informative about the behaviour of policymakers. However, if governments for political reasons have an incentive to manipulate those figures and institutional arrangements are too weak to prevent this from happening, first-release figures may lose their usefulness as indicators of the eventual outcomes and as an input into the budgetary process.

Related to this paper is De Castro et al. (2011), who explore the properties of subsequent revisions in the budget balances of a given year. Our results confirm their finding that preliminary data releases are biased estimators of the final data. At the same time, our analysis neatly complements their approach. While they focus in more detail on the data revision process of the budget balance using Excessive Deficit Procedure (EDP) notifications, in studying errors we cover the whole budgetary cycle from plan to implementation and expost control, although our emphasis is on revision errors. More importantly, in contrast to

\footnotetext{
${ }^{3}$ Exceptions are Balassone et al. (2006, 2007), who compare the quality of alternative indicators for fiscal discipline and conclude that a major shortcoming of deficits in this regard is that they are often subject to substantial revisions. They also argue that consistency cross-checks between deficits and debt changes may offer useful monitoring information. Gordo and Nogueira Martins (2007) provide a descriptive analysis of revisions in EDP debt and deficit data.

${ }^{4}$ Since the early 2000s such evaluation has become a standard practice in the assessment by the European Commission of the national Stability and Convergence Programmes.
} 
their work, but also in contrast to Beetsma et al. (2009), we provide an explicit framework for decomposing overall errors into their components. This includes the revenue and expenditure side of the budget, but also a further decomposition of errors on each side of the budget. Moreover, we stress the political-economy effects of real-time estimations by the Ministry of Finance versus final data as produced by the statistical office. Finally, we explore the role of budgetary institutions in countering biases. The originality of our approach is mainly in systematically analysing the sources of the revision biases and the components of those revision biases.

The European Commission also applies our decomposition framework in its regular fiscal surveillance of individual stability and convergence programmes. Our approach differs as we apply the decomposition to all countries and all years, ${ }^{5}$ in order to identify systematic patterns, and apply it to implementation errors as well as revision errors. This provides the starting point for an empirical analysis that links revision errors and their components to economic, political and institutional variables.

Our main findings are the following. First, while fiscal plans are on average too optimistic relative to the first-release outcomes, a result in line with much of the related literature, first-release figures are in turn overly optimistic relative to the final, ex-post figures. ${ }^{6}$ Given their control over the production of first-release figures, governments may be tempted to be over-optimistic at this stage. We find that while most of the over optimism at the planning stage relative to the first-release stage is driven by expenditures, revision errors are mainly caused by over optimism about revenues at the first-release stage. We find that a substantial part of the over-optimism arises from the base effect, that is, the revision of the previous period's balance in the light of this year's new information. The remainder arises from the so-called "growth effect", which is related to the difference in the growth of nominal revenues versus the growth in nominal expenditures. Further, our regression analysis suggests that economic factors play a limited role in explaining the revision bias and its components, while political factors play virtually no role at all. By contrast, institutional arrangements do seem to be important. An improvement in the quality of national fiscal institutions, whether one measures them through the tightness of fiscal rules, the medium-term budgetary framework or the degree of transparency, reduces the degree of optimism at the first-release

\footnotetext{
${ }^{5}$ For example, the 2010 macro fiscal assessment (MFA) for Belgium applies the decomposition to 2008 and 2009 for Belgium only. See the formula in Footnote 7 on page 11 in http://ec.europa.eu/economy_finance/sgp/pdf/20_scps/2009-10/02 technical_assessment/be_2010-0331 ta_en.pdf. Since 2008 the Commission applies the decomposition in the MFAs of all the countries.

${ }^{6}$ This result is consistent with De Castro et al. (2011), who find that initial releases of government deficits in the EDP notifications are biased predictors of subsequent releases, with later vintages showing larger deficits.
} 
stage and makes first-release figures more informative about the eventual outcomes. These findings support the European Commission's (2010) proposal to specify minimum requirements for domestic fiscal frameworks, a proposal that is likely to be accepted by the European Council (Heads of Government or State of the EU). These minimum requirements concern in particular the adoption of properly designed numerical fiscal rules and mediumterm budgetary frameworks as well as requirements on transparency. The European Parliament's (2011) amendment proposals on national ownership go even further by requiring euro-area countries to incorporate the objectives of the Stability and Growth Pact into national law and to elaborate national budgetary frameworks that ensure compliance with these objectives.

Our analysis may also shed some light on earlier (seemingly) conflicting results in the literature. Specifically, while it is generally found that fiscal plans tend to be too optimistic relative to the subsequent outcomes, views differ on the origins of the fiscal slippages. One reason for this may be the use of first-release versus ex-post data. Most, though not all, studies conclude that fiscal slippages in the EU are dominated by slippages on the expenditure side. However, Von Hagen (2010) finds that slippages (in levels over the period 1998-2004) can be attributed to the revenue side of budget, a difference that may at least partly be explained by his use of ex-post data. An additional reason concerns the measure of fiscal slippages that is used. For instance, in contrast to Von Hagen (2010), who explores total errors, Moulin and Wierts (2006) focus on the growth effect in the deviations of ex-post from planned fiscal figures over the period 1998-2006. They find that slippages in EU budget balances can be mostly attributed to nominal expenditures.

The remainder of this paper is structured as follows. Section 2 provides a conceptual framework for why ex-post fiscal outcomes may differ from first-release figures. This section also decomposes implementation and revision errors into their components. The regression analysis in Section 3 explores the role of economic, political and institutional factors in explaining revision errors, while Section 4 concludes the paper.

\section{Conceptual framework and decompositions}

In this section, we first describe how systematic revision errors in fiscal policy may arise, after which we present the formal decompositions of the deviations of the first-release budgetary outcomes from their planned values and the ex-post outcomes from their first- 
release outcomes. Finally, we present summary statistics for both stages of the decomposition.

\subsection{Sources of fiscal slippages}

The budget process consists of three stages, the planning stage, the implementation stage and the ex-post control stage. To understand implementation and revision biases, we should know (i) who controls and reports the fiscal figures, and (ii) what are the incentives under which these figures are reported?

During the planning stage, it is the cabinet that agrees on the budget and the medium term fiscal plan in the stability program. Beetsma et al. (2009) describe why the planned budget balance may be deliberately optimistic. In sum, during planning, fiscal policymakers are required to present an adjustment path as demanded by the preventive arm of the SGP. At the same time, they may also want to signal to the public that they respond to the many spending needs in society. Tools for hiding this trade off include systematic optimism in growth and revenue projections.

At the same time, countries with a better starting position are under less pressure from the EU fiscal rules during planning. National fiscal rules may prescribe cautious or realistic growth projections or fiscal planning, in order to prevent implementation biases later on. This is the case that Beetsma et al. (2010) describe for The Netherlands.

Our measure of first-release implementation is the projected value of the budget balance for year $t$ as estimated towards the end of year $t$. This is still an estimate produced by the Ministry of Finance during the current fiscal year. Balassone et al. (2006) describe the large degree of uncertainty under which real time estimations of the deficit are made, which is partly related to the use of accrual data. We conjecture that the margin for discretion in real time fiscal data may be larger for revenues than for expenditure. During the fiscal year, the Ministry of Finance has a direct control over revenue projections, while expenditure estimations also depend on input from the spending ministries. Its margin for strategic use of revenue projections may also be larger since revenue developments are endogenous to the economic cycle, and depend on seasonal patterns. Expenditure, on the other hand, is more under the direct control of the spending ministries.

The empirical evidence in Beetsma et al. (2009) indeed confirms that for the EU-14 countries as a whole, implementation as measured by the first-release outcomes falls short of what was planned. Moreover, biases are concentrated on the expenditure side. Part of the 
explanation lies in the systematic shortfalls of real growth relative to projected growth. However, governments may also deliberately deviate from their original spending plans. ${ }^{7}$ In line with these findings, regressions show that implementation biases are to a substantial degree predictable. They are related to economic, political and institutional factors.

As indicated already, incentives will be different for countries less under pressure of the EU fiscal rules. For countries with better starting positions, at the planning stage the Ministry of Finance may try to counterbalance the effect of spending pressures on the budget balance by using deliberately cautious revenue projections. This is the pattern that is found in Beetsma et al.'s (2010) case study on The Netherlands.

In this paper we follow up on earlier work by investigating the empirical determinants of the deviations of the ex-post budgetary outcomes from their first-release values. In almost all EU Member States it is the national statistical office that is responsible for compiling the budget balance data once the fiscal year is over. ${ }^{8}$ Given the independent position of statistical offices in most countries ${ }^{9}$, we expect ex post data to be free from political distortions. However, as indicated, real-time data may be used strategically by the Ministry of Finance.

In this setting revision errors may arise for several reasons. First, ex-post outcomes may differ from their first-release counterparts if implementation differs from planned fiscal policy for the last months of the year implicit in the first-release estimate. In other words, our findings may be partially determined by implementation biases of the type discussed above.

Second, data revisions may drive a wedge between ex-post and first-release fiscal outcomes. Revisions may occur for various reasons, such as new information on government transactions, the identification of errors or inconsistencies, changing insights on how to best comply with the accounting rules and changes in the accounting rules themselves (see Gordo and Nogueira Martins, 2007, and De Castro et al., 2011). While one would a priori not expect accounting revisions to produce systematic biases into one or the other direction, De Castro et al. (2011) point out that "so-called Eurostat decisions reflect the need to monitor in detail practices by national statistical institutes that tend to be close to the limit of the interpretation

\footnotetext{
7 The OECD questionnaire on budgeting practices and procedures (OECD, 2008) suggests that in all EU countries for which this information is available the government is allowed to increase mandatory spending after the legislature has approved the budget. Specifically, the relevant questions are "Q.51.a.1. Increase mandatory spending - is it possible?”, “Q.51.a.2. Increase mandatory spending - does it require any approval?”, “Q.51.b.1. Increase discretionary spending - is it possible?” and “Q.51.b.2. Increase discretionary spending - does it require any approval?”

${ }^{8}$ An exception is Belgium, where the national central bank compiles the data for the deficit.

${ }^{9}$ In Greece, the Ministry of Finance has been involved in the compilation of EDP data for the deficit and the debt.
} 
of existing legislation at each point in time.” Hence, most of the Eurostat decisions result in an upward revision of a deficit figure.

Third, given that it is the Ministry of Finance that produces the first-release figures these figures may be affected by political-strategic motives. In particular, because fiscal data are recorded on an accrual basis, the Ministry of Finance has some margin left in the publication of the first-release revenues figures.

What the control over the first-release data by the Ministry of Finance implies for the revision bias depends also on the budgetary constraints under which the government operates. First, Milesi-Ferreti (2003) presents a theoretical framework in which the first-release fiscal outcomes in period $t$ cannot be measured with complete precision, which is a realistic assumption as we explained above. Since externally enforced fiscal rules apply to the measured first-release balance, there is an incentive for creative accounting at this stage. Hence, empirically, we expect the chosen degree of creative accounting to depend on the extent to which external fiscal rules are also binding in terms of first-release figures. Governments tend to discount the future at a high rate and may resort to creative accounting at the first-release stage, even though they know that the ex-post figures will in the end reveal current fiscal slippages. This discussion suggests the hypothesis of a systematically negative revision error (ex-post minus first-release balance), because during the period under consideration our sample countries have been subject to the Stability and Growth Pact (SGP), which operates partly on the basis of the first-release figures reported by the EU member states. ${ }^{10}$ Second, on the basis of the case study by Beetsma et al. (2010) for the Netherlands, we may conjecture that tighter national fiscal rules, which serve as a self-enforced commitment device implying that the Ministry of Finance takes more responsibility for "prudent" fiscal outcomes, lead to less over-optimism at the first-release stage and, hence, smaller revision errors in absolute magnitude. Third, under those circumstances when the government has an incentive to resort to creative accounting at the first-release stage, we would expect the degree of creative accounting to be negatively related to the degree of transparency of the budget and thus revision biases to be smaller in absolute magnitude, as more transparency reduces the opportunities for creative accounting.

\footnotetext{
${ }^{10}$ Interestingly, Heinemann (2006), who investigates the quality of medium-term fiscal planning in Germany finds that over-optimism in financial projections has increased after the Maastricht Treaty came into effect.
} 


\subsection{The decompositions}

Consider some variable $x$, which can be $R E V$ (revenues as a share of GDP), EXP (government spending as a share of GDP) or $B A L$ (the budget balance as a share of GDP). The first-release (when $\tau=t$ ) and ex-post (when $\tau=f$, where $f$ stands for "final") outcome of the variable can be decomposed into its originally planned value and a deviation from the plan (the “implementation error”):

$$
x_{t}^{\tau}=x_{t}^{t-1}+\left(x_{t}^{\tau}-x_{t}^{t-1}\right)
$$

A superscript on a variable denotes the vintage (year) when it is published, while the subscript denotes the year to which the observation refers. For example, suppose that $x=B A L$. Then, $B A L_{t}^{t-1}$ is the balance over GDP ratio planned in the Fall of year $t-1$ for year $t, B A L_{t}^{t}$ is the first-release figure for year $t$ released in the Fall of year $t$ and $B A L_{t-1}^{t}$ is the revised figure for year $t-1$ released in the Fall of year $t$. For convenience, variables are always expressed without a country index.

The decompositions (1) for the balance, expenditures and revenues are linked as follows:

$$
\begin{aligned}
& B A L_{t}^{\tau}=B A L_{t}^{t-1}+\left(B A L_{t}^{\tau}-B A L_{t}^{t-1}\right)= \\
& {\left[R E V_{t}^{t-1}+\left(R E V_{t}^{\tau}-R E V_{t}^{t-1}\right)\right]-\left[E X P_{t}^{t-1}+\left(E X P_{t}^{\tau}-E X P_{t}^{t-1}\right)\right] .}
\end{aligned}
$$

For $x=R E V$ and $x=E X P$ we can further decompose the (total) first-release (when $\tau=t$ ) and ex-post (when $\tau=f$ ) error $T E=x_{t}^{\tau}-x_{t}^{t-1}$ as follows: ${ }^{11}$

$$
\begin{array}{ll}
e(x)_{t}^{\tau, t-1} \equiv x_{t}^{\tau}-x_{t}^{t-1} & \\
=\frac{1+g_{x, t}^{t-1}}{1+y_{t}^{t-1}}\left(x_{t-1}^{\tau}-x_{t-1}^{t-1}\right) & \text { base effect }
\end{array}
$$

\footnotetext{
${ }^{11}$ This decomposition is related to the "growth accounting" procedure in Von Hagen et al. (2002), which separates the effects of economic growth and fiscal contraction on fiscal consolidation.
} 


$$
\begin{array}{ll}
+\frac{x_{t-1}^{\tau}}{\left(1+y_{t}^{\tau}\right)\left(1+y_{t}^{t-1}\right)}\left(g_{x, t}^{\tau}-g_{x, t}^{t-1}\right) & \text { growth effect } \\
-\frac{x_{t-1}^{\tau}}{\left(1+y_{t}^{\tau}\right)\left(1+y_{t}^{t-1}\right)}\left(y_{t}^{\tau}-y_{t}^{t-1}\right) & \text { denominator effect } \\
+\frac{x_{t-1}^{\tau}}{\left(1+y_{t}^{\tau}\right)\left(1+y_{t}^{t-1}\right)}\left(g_{x, t}^{\tau} y_{t}^{t-1}-g_{x, t}^{t-1} y_{t}^{\tau}\right) & \text { residual effect. }
\end{array}
$$

Here, $g_{x, t}^{t-1}$ is the planned growth rate in the level (in euro's) of nominal revenues (if $x=R E V$ ) or nominal spending (if $x=E X P$ ) over period $t$. Further, $g_{x, t}^{\tau}$ is the corresponding actual growth rate over the same period as measured towards the end of period $\tau$ (where $\tau$ is $t$ or $f$ ). Finally, $y_{t}^{t-1}$ is the projected nominal income growth rate and $y_{t}^{\tau}$ is the actual nominal income growth rate as measured towards the end of period $\tau$ (where $\tau$ is $t$ or $f$ ). The total error for $x=B A L$ and its four effects are calculated by subtracting the decomposition in (3) for spending from that for revenues. This yields the base, growth, denominator and residual effects for the total error in the budget balance.

The base effect $B E$ contains new information on the starting (period $t-1$ ) position of the fiscal stance and, therefore, when compared with the planning stage it represents a positive or negative fiscal surprise when fiscal measures are implemented. It captures the part of the error that is due to the difference between the outcome (as measured one year later or ex post) of a variable in a given year $t-1$ and its first release for that year. Apart from statistical revisions in fiscal data, it may also arise from statistical revisions that lead to a shift in the level of GDP. For example, if the level of GDP is revised upwards, the revenue and expenditure ratios both move downwards, while the effect on the balance largely cancels out.

The growth effect $G E$ constitutes the part of the surprise in budgetary adjustment that arises from deviations of nominal revenue or expenditure growth from their planned values. Those deviations may arise for various reasons. For example, they may be due to unexpected macroeconomic developments and overambitious planning (European Commission, 2007). In the case of revenues, deviations of tax elasticities from their expected values may also play a role. $^{12}$ The denominator effect $D E$ arises from projection errors in nominal output growth. If

\footnotetext{
${ }^{12}$ Of course, spending elasticities may also differ from their predicted values. However, this is unlikely to be a substantial contributor to the growth effect, because spending elasticities are thought to be relatively small in absolute magnitude as spending contains only few items that are cyclically sensitive.
} 
the growth rate turns out to be higher than projected, both the revenue and expenditure ratios will fall short of their planned values. However, because both ratios move into the same direction, the denominator effects in the spending and revenue ratios largely cancel out against each other implying that the denominator effect in the budget balance is likely to be small. Finally, the residual component $R E$ is usually of negligible size, as it is a second-order term formed by the product of growth rates. It will not receive any further attention in our analysis.

In the following, we will compare the decompositions of the first-release and ex-post errors. However, we are also interested in the difference between ex-post and first-release errors. The relationship between these errors is given by:

$$
e(x)_{t}^{f, t-1}=\left(x_{t}^{f}-x_{t}^{t}\right)+\left(x_{t}^{t}-x_{t}^{t-1}\right)=e(x)_{t}^{f, t}+e(x)_{t}^{t, t-1},
$$

where $e(x)_{t}^{t, t-1}=x_{t}^{t}-x_{t}^{t-1}$. In other words, the difference between the two errors is the base effect for variable $x$ in period $t$. However, as we have argued earlier, we want to dig further into the sources of this new base effect. To study those sources we decompose analogous to (3) the difference between the ex-post and first-release outcomes for $x=R E V$ and $x=E X P$ :

$$
\begin{array}{ll}
e(x)_{t}^{f, t}=x_{t}^{f}-x_{t}^{t} & \\
=\frac{1+g_{x, t}^{t}}{1+y_{t}^{t}}\left(x_{t-1}^{f}-x_{t-1}^{t}\right) & \text { base effect } \\
+\frac{x_{t-1}^{f}}{\left(1+y_{t}^{f}\right)\left(1+y_{t}^{t}\right)}\left(g_{x, t}^{f}-g_{x, t}^{t}\right) & \text { growth effect } \\
-\frac{x_{t-1}^{f}}{\left(1+y_{t}^{f}\right)\left(1+y_{t}^{t}\right)}\left(y_{t}^{f}-y_{t}^{t}\right) & \text { denominator effect } \\
+\frac{x_{t-1}^{f}}{\left(1+y_{t}^{f}\right)\left(1+y_{t}^{t}\right)}\left(g_{x, t}^{f} y_{t}^{t}-g_{x, t}^{t} y_{t}^{f}\right) & \text { residual effect, }
\end{array}
$$

while the corresponding effects for $x=B A L$ again follow by subtracting the decomposition for spending from that for revenues. Notice that, whereas the total revision error in the firstrelease observations equals the difference between the ex-post and first-release errors 
calculated under (3), this is not the case for the individual effects of the decompositions. However, the differences are of second-order importance. ${ }^{13}$

\subsection{The data}

Our planning and first-release data are from the EU Stability and Convergence Programs (SCPs) submitted in the years 1998-2008. The SCPs are generally published in November or December. Therefore, the budgetary projections contained in those data should be close to the official budget. The advantage of using the SCPs is that they constitute a harmonised source of data on fiscal plans and outcomes in EU countries. Our ex-post figures are taken from the November 2010 AMECO dataset. Given that it may take up to four years to arrive at the “truly” final data (see Gordo and Nogueira Martins, 2007, and De Castro et al., 2011), for the latest vintages of our SCP data we do not have the eventual outcomes, although they will likely be close to the final figures. Most of the data revision tends to be concentrated in the first two years after the first release. Indeed, De Castro et al. (2011) find very little change on average after these two years. Our sample covers Austria, Belgium, Denmark, Germany, Greece, Finland, France, Ireland, Italy, The Netherlands, Portugal, Spain, Sweden and the U.K. Only the U.K. has a fiscal year that differs from the calendar year. However, in November or December of each year the Chancellor of the Exchequer presents the 'PreBudget Report', which also contains an update of the public finances and proposed new tax measures. In the sequel, the "sample period" will always indicate the years to which the observations refer (i.e., subscript of a variable) as opposed to the vintages from which the data are taken (i.e., superscript of a variable). We also use data on political variables from Armingeon et al. (2010), supplemented by self-constructed figures for the year 2009, and on institutional indices from various sources. These are described below. Details on all the data are found in the Appendix A.

\footnotetext{
${ }^{13}$ For instance, in the case of the base effect, $\frac{1+g_{x, t}^{t}}{1+y_{t}^{t}}\left(x_{t-1}^{f}-x_{t-1}^{t}\right)$ differs from the difference between the base effects of the ex-post and real-time errors $\frac{1+g_{x, t}^{t-1}}{1+y_{t}^{t-1}}\left(x_{t-1}^{f}-x_{t-1}^{t}\right)$ because in general $\frac{1+g_{x, t}^{t}}{1+y_{t}^{t}} \neq \frac{1+g_{x, t}^{t-1}}{1+y_{t}^{t-1}}$. However, the difference is usually small.
} 


\subsection{Outcomes of the decompositions}

Figure 1 depicts planned budgets and first-release and ex-post budgetary outcomes for each country and each year in our sample. Clearly, both the implementation errors and the revision errors are often substantial. Moreover, there is no obvious visible difference in their average size. It may be instructive to comment on some specific cases. First, we see that in the case of Greece, in all but two years the first-release balance falls short of the planned balance, while the ex-post balance is always lower and sometimes substantially lower than the first-release balance. Secondly, we observe large negative spikes for Austria and Belgium in 2004 and 2005, respectively. The spike for Austria is the result of a 1.4 billion euro capital injection into the railway company and a 6.1 billion euro debt assumption of the railway company by the state. Both transactions were reclassified afterwards by Eurostat as deficit-increasing measures. The spike for Belgium is related to a split-up of the Belgian National Railway Company, in which the company's debts were transferred to a separate entity. Eurostat held the view that this should be recorded as a 7.4 billion deficit-increasing capital transfer by the Belgian federal government. While both spikes may capture rather extreme shortfalls of expost from the first-release outcomes, we choose to keep them in our sample, because they are prima-facie examples of the sources of revision errors described above. In fact, leaving out these two observations for Austria and Belgium yields results that are qualitatively and quantitatively very similar to those obtained below. ${ }^{14}$

Before turning to the discussion of our error decomposition for the budget balance and its components, we explore first the corresponding errors in output growth, as those errors may be a driving force behind errors in the budget balance. These errors are reported in Table 1 for nominal output, real output and the GDP deflator. Projections at the planning stage are overoptimistic relative to the first-release stage, but not relative to the eventual outcomes. The over-optimism relative to the first-release is larger for real output than for nominal output, because inflation is projected too low.

Table 2 shows the averages over all observations of the aforementioned decompositions of first-release minus planned budgetary figures, ex-post minus planned figures and ex-post minus first-release figures, respectively. While the focus of this paper is mostly on revision errors, i.e. the difference between ex-post and first-release figures, it is instructive to present the complete decompositions for the various stages. This enables us to

\footnotetext{
${ }^{14}$ De Castro et al. (2011, Section 2.2) mention examples of major revisions in EDP data. Their Table A.1 lists the Eurostat decisions leading to revision.
} 
compare the sizes of the implementation errors and the revision errors as well as the sources of these errors. It also helps us in reconciling various results in the literature.

\section{Figure 1: Planned, first-release and ex-post balances}
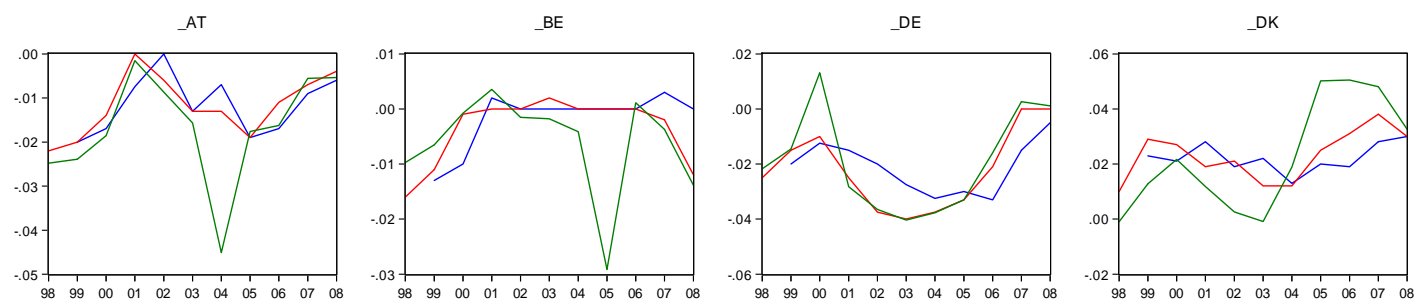

ES
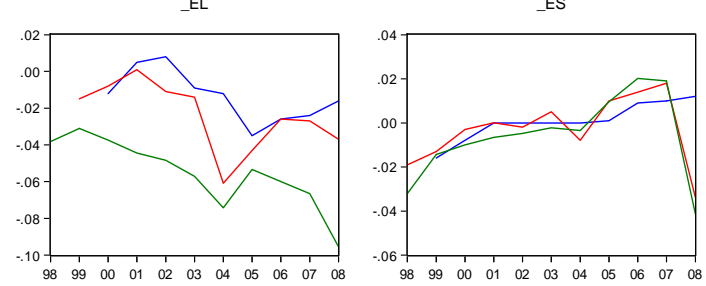

F

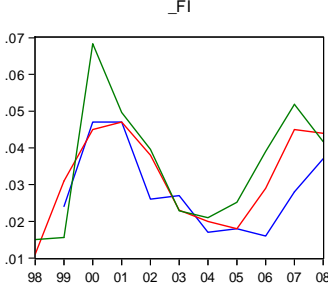

FR

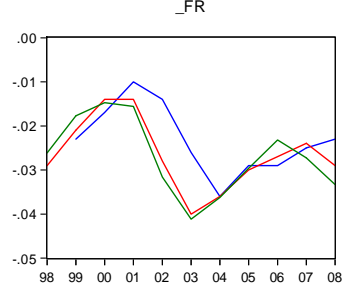

IT

NL
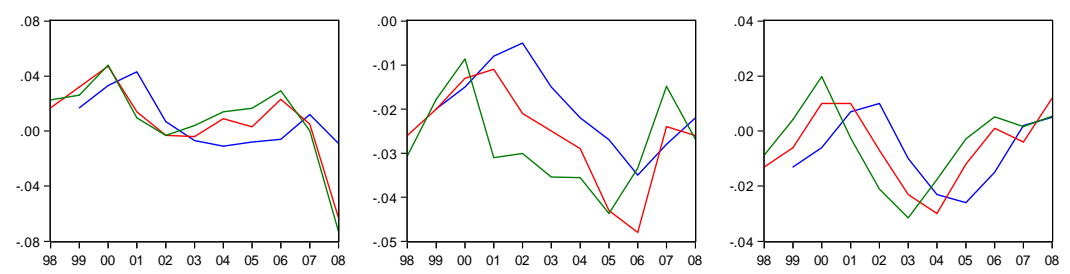

PT
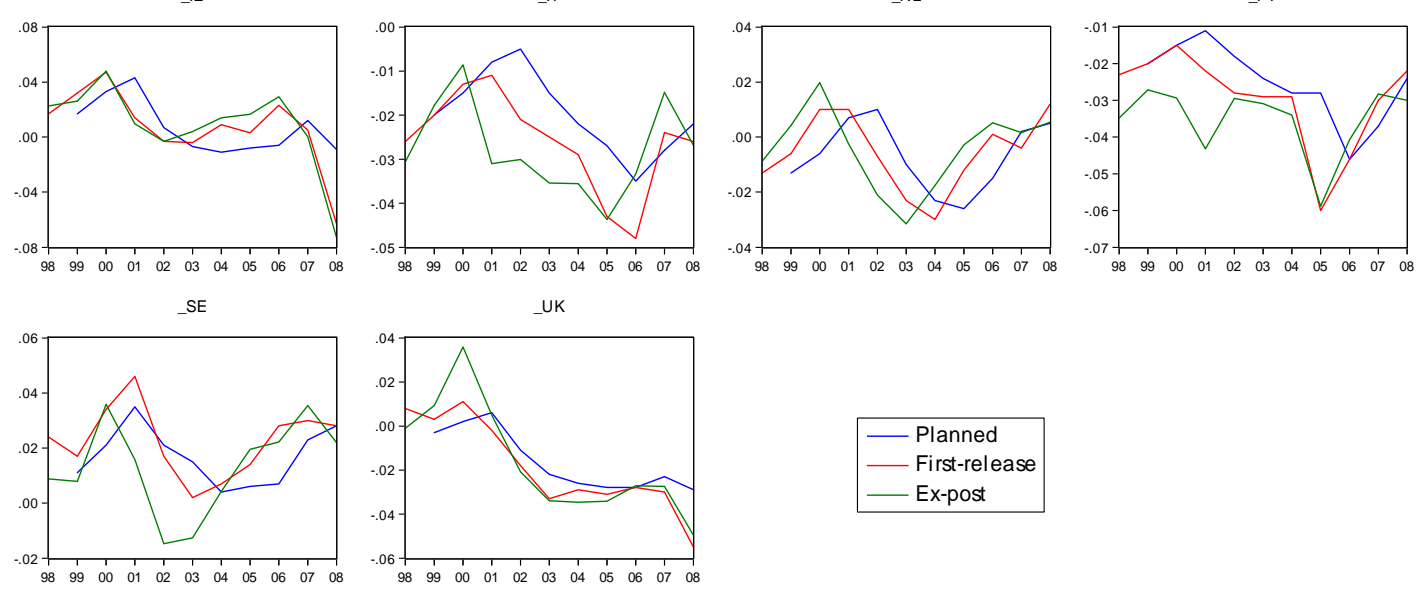

UK

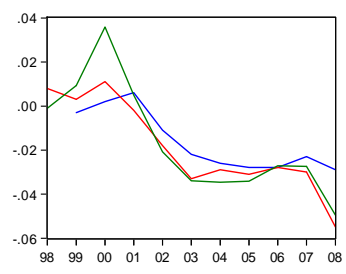

Table 1: Forecast errors in average GDP and the GDP deflator

\begin{tabular}{|c|c|c|c|}
\hline & Nominal GDP & Real GDP & GDP deflator \\
\hline First release & $-0.20^{*}$ & $-0.32^{* * *}$ & $0.11^{*}$ \\
minus plan & $(0.12)$ & $(0.09)$ & $(0.06)$ \\
\hline Ex post minus & 0.06 & -0.07 & $0.13^{*}$ \\
plan & $(0.16)$ & $(0.13)$ & $(0.08)$ \\
\hline Ex post minus & $0.26^{* * *}$ & $0.22^{* * *}$ & 0.03 \\
first release & $(0.09)$ & $(0.06)$ & $(0.05)$ \\
\hline
\end{tabular}

Notes: Forecast errors are expressed in percent. Standard errors (corrected for heteroskedasticity and serial correlation) are reported underneath. Further, * = significance at the $10 \%$ level; ** = significance at the $5 \%$ level; $* * *=$ significance at the $1 \%$ level. The sample period is $1999-2008$, except for the expost minus first-release errors, in which case the sample period is 1998-2008. 
We first discuss the decomposition of the first-release and ex-post errors relative to planned budgetary values reported in panels (A) and (B) of Table 2. Not surprisingly, in view of earlier results from the literature, we see that the total budget balance error is negative and significant in both cases, indicating a systematic over-optimism in budgetary plans. Importantly, the shortfall from the planned balance is on average larger in the ex-post errors, where it is $-0.50 \%$ of GDP, than in the first-release errors, where it is $-0.17 \%$ of GDP. Table 2 also reports the percentage of observations below zero in each case. Given that in the case of the first-release errors only around half of the observations lie below zero, the size of the shortfalls of the balance relative to plan tends to dominate the instances in which first-release implementation is better than planned.

The decomposition of the total error into its different components allows us to trace its main source(s). We observe a significantly positive base effect for the first-release errors and a significantly negative (and substantially larger in absolute value) base effect for the ex-post errors, implying a substantial negative base effect of $-0.42 \%$ of GDP going from first-release to ex-post data (see Panel (C) of Table 2, discussed below). The growth effect is significantly negative (-0.25\% GDP) for the first-release errors and negative but insignificant for the expost errors. Finally, the denominator effects are essentially zero for both the first-release and ex-post errors, which is the result of the denominator effects in revenues and expenditures roughly cancelling out.

Next, we split the total errors for the balance into total errors for revenues minus total errors for expenditures. In line with our earlier conjecture, we see that the expenditure side essentially explains the first-release errors, although the expenditure error is not statistically significant, while the revenue side mainly explains the ex-post errors. This may explain why Von Hagen (2010) attributes slippages to the revenue side, while other authors associate them with the expenditure side.

The total errors in the budget components can also be split into four separate effects each. We find that the base effects in both components are insignificant for the first-release errors and significantly negative and large in absolute terms for the ex-post data. Here, the base effect in revenues dominates that in expenditures, resulting in an overall negative effect for the budget balance. On the basis of the base effect alone, at the first-release stage governments would appear more disciplined than in their plans, while the ex-post stage shows that they have been substantially less disciplined than planned. For the first-release errors the growth effect is insignificant in the case of revenues and significantly positive in the case of expenditures. In other words, nominal expenditure growth has exceeded planned growth on 
average. The ex-post data reveal a positive and significant growth effect for both revenues and expenditures, with the effect for the latter almost double that for the former. Finally, in the first-release errors the denominator effect is significantly negative for both revenues and expenditure, implying an increase in the total error for each of the budget components. These negative denominator effects are explained by actual GDP growth falling short of its projection. In the ex-post data the denominator effect is insignificant for both revenues and expenditures, which is in line with the finding that actual GDP in the ex-post data does not significantly differ from projected GDP.

Turning to the revision errors reported in Panel (C) of Table 2, we see that the total error is on average negative. While plans are too optimistic relative to the first-release outcomes, the latter in turn are too optimistic relative to the eventual, ex-post outcomes. This is in line with our discussion that Ministries of Finance may have an incentive to depict their budgetary achievements too positively in real time (recall Section 2.1). The total revision error is largely driven by a negative update on previous period's balance (the base effect). A split into revision errors on the revenues and expenditure sides shows that in line with our earlier conjecture most of the action is on the revenues side. As we argued above, given that our data are on an accrual, rather than cash, basis, there is room for deliberate over-optimism in the first-release revenues data. Indeed, these data overestimate the eventual outcome by $0.60 \%$ of GDP on average. This effect is driven by a substantial negative base effect of almost three-quarters of a percent of GDP on average, which is partially compensated for by a growth effect in revenues and a positive denominator effect due to the pessimism about output growth at the first-release stage. Not surprisingly, because the revenues and expenditure shares in GDP are of comparable magnitude, the denominator effect in revenues is wiped out by an equally-sized denominator effect in expenditure, thereby producing a total denominator effect of roughly zero in the balance. Finally, the growth effect in revenues dominates the growth effect in expenditures, but by not nearly enough to offset the difference in the base effects. The negative base effect for both revenue and expenditure is consistent with the systematic upward revisions in GDP that occurred in 2005 (while the effects of this GDP revision on the balance almost fully cancel out). This revision covered all countries in our sample and was applied backwards to even beyond the start of our sample period. ${ }^{15}$

\footnotetext{
${ }^{15}$ See http://epp.eurostat.ec.europa.eu/cache/ITY_PUBLIC/NATIONAL_2005/EN/NATIONAL_2005-EN.PDF. This level increase varies across Member States and years, but roughly ranges between $0.5 \%$ and $2.0 \%$. Hence, if the revenue and expenditure ratios were $50 \%$ of GDP, the effect on these ratios would be roughly between 0.25 and 1.0 percentage points of GDP. No systematic effect on GDP growth rates is observed.
} 
Table 2. Decomposition of errors in the budget and its components

\begin{tabular}{|c|c|c|c|c|c|}
\hline \multicolumn{6}{|c|}{ (A) Implementation errors based on first-release data minus plans } \\
\hline & TE & BE & GE & DE & RE \\
\hline$B A L$ & $\begin{array}{l}-0.17^{*} \\
(0.10) \\
{[51 \%]}\end{array}$ & $\begin{array}{l}0.10^{*} \\
(0.06) \\
{[39 \%]}\end{array}$ & $\begin{array}{c}-0.25 * * * \\
(0.08) \\
{[59 \%]}\end{array}$ & $\begin{array}{c}0.00 \\
(0.00) \\
{[43 \%]}\end{array}$ & $\begin{array}{c}-0.01 * * \\
(0.01) \\
{[60 \%]}\end{array}$ \\
\hline$R E V$ & $\begin{array}{c}0.02 \\
(0.12) \\
{[48 \%]}\end{array}$ & $\begin{array}{l}-0.05 \\
(0.11) \\
{[45 \%]}\end{array}$ & $\begin{array}{l}-0.04 \\
(0.08) \\
{[53 \%]}\end{array}$ & $\begin{array}{c}-0.11 * * \\
(0.05) \\
{[53 \%]}\end{array}$ & $\begin{array}{c}0.00 \\
(0.00) \\
{[47 \%]}\end{array}$ \\
\hline$E X P$ & $\begin{array}{c}0.19 \\
(0.12) \\
{[43 \%]}\end{array}$ & $\begin{array}{l}-0.15 \\
(0.11) \\
{[55 \%]}\end{array}$ & $\begin{array}{c}0.21 * * * \\
(0.05) \\
{[36 \%]}\end{array}$ & $\begin{array}{c}-0.11 * * \\
(0.05) \\
{[53 \%]}\end{array}$ & $\begin{array}{c}0.02 * * * \\
(0.004) \\
{[34 \%]}\end{array}$ \\
\hline PEXP & $\begin{array}{c}0.25 * * \\
(0.13) \\
{[38 \%]}\end{array}$ & $\begin{array}{l}-0.10 \\
(0.10) \\
{[52 \%]}\end{array}$ & $\begin{array}{c}0.22 * * * \\
(0.05) \\
{[31 \%]}\end{array}$ & $\begin{array}{c}-0.11 * * \\
(0.05) \\
{[54 \%]}\end{array}$ & $\begin{array}{c}0.02 * * * \\
(0.00) \\
{[31 \%]}\end{array}$ \\
\hline \multicolumn{6}{|c|}{ (B) Implementation errors based on ex-post data minus plans } \\
\hline & TE & $\mathbf{B E}$ & GE & DE & RE \\
\hline$B A L$ & $\begin{array}{c}-0.50 * * * \\
(0.17) \\
{[58 \%]}\end{array}$ & $\begin{array}{c}-0.32 * * * \\
(0.11) \\
{[57 \%]}\end{array}$ & $\begin{array}{l}-0.17 \\
(0.13) \\
{[56 \%]}\end{array}$ & $\begin{array}{c}0.00 \\
(0.00) \\
{[53 \%]}\end{array}$ & $\begin{array}{l}-0.01 * \\
(0.01) \\
{[55 \%]}\end{array}$ \\
\hline$R E V$ & $\begin{array}{c}-0.59 * * * \\
(0.21) \\
{[61 \%]}\end{array}$ & $\begin{array}{c}-0.79 * * * \\
(0.19) \\
{[67 \%]}\end{array}$ & $\begin{array}{l}0.19 * \\
(0.10) \\
{[39 \%]}\end{array}$ & $\begin{array}{c}0.01 \\
(0.06) \\
{[49 \%]}\end{array}$ & $\begin{array}{c}0.01 \\
(0.00) \\
{[41 \%]} \\
\end{array}$ \\
\hline$E X P$ & $\begin{array}{l}-0.09 \\
(0.18) \\
{[52 \%]}\end{array}$ & $\begin{array}{c}-0.48 * * * \\
(0.16) \\
{[62 \%]}\end{array}$ & $\begin{array}{c}0.36 * * * \\
(0.09) \\
{[33 \%]}\end{array}$ & $\begin{array}{c}0.00 \\
(0.06) \\
{[49 \%]}\end{array}$ & $\begin{array}{c}0.02 * * * \\
(0.01) \\
{[39 \%]}\end{array}$ \\
\hline PEXP & $\begin{array}{c}0.13 \\
(0.18) \\
{[44 \%]}\end{array}$ & $\begin{array}{l}-0.29 * \\
(0.16) \\
{[58 \%]}\end{array}$ & $\begin{array}{c}0.39 * * * \\
(0.09) \\
{[31 \%]}\end{array}$ & $\begin{array}{c}0.00 \\
(0.06) \\
{[49 \%]}\end{array}$ & $\begin{array}{c}0.02 * * * \\
(0.01) \\
{[37 \%]}\end{array}$ \\
\hline \multicolumn{6}{|c|}{ (C) Revision errors based on ex-post data minus first-release data } \\
\hline & TE & BE & GE & DE & RE \\
\hline$B A L$ & $\begin{array}{c}-0.34 * * * \\
(0.11) \\
{[59 \%]}\end{array}$ & $\begin{array}{c}-0.42 * * * \\
(0.08) \\
{[71 \%]}\end{array}$ & $\begin{array}{c}0.07 \\
(0.08) \\
{[48 \%]}\end{array}$ & $\begin{array}{l}-0.00 \\
(0.00) \\
{[53 \%]}\end{array}$ & $\begin{array}{l}-0.00 \\
(0.00) \\
{[48 \%]}\end{array}$ \\
\hline$R E V$ & $\begin{array}{c}-0.60 * * * \\
(0.18) \\
{[66 \%]}\end{array}$ & $\begin{array}{c}-0.74 * * * \\
(0.16) \\
{[74 \%]}\end{array}$ & $\begin{array}{c}0.22 * * * \\
(0.06) \\
{[34 \%]}\end{array}$ & $\begin{array}{c}0.10 * * * \\
(0.03) \\
{[41 \%]}\end{array}$ & $\begin{array}{c}0.01 \\
(0.00) \\
{[38 \%]}\end{array}$ \\
\hline$E X P$ & $\begin{array}{l}-0.26 \\
(0.16) \\
{[58 \%]}\end{array}$ & $\begin{array}{c}-0.32 * * \\
(0.15) \\
{[61 \%]}\end{array}$ & $\begin{array}{l}0.14^{*} \\
(0.08) \\
{[41 \%]}\end{array}$ & $\begin{array}{c}0.10 * * * \\
(0.03) \\
{[41 \%]}\end{array}$ & $\begin{array}{c}0.01 \\
(0.00) \\
{[45 \%]}\end{array}$ \\
\hline$P E X P$ & $\begin{array}{l}-0.05 \\
(0.15) \\
{[53 \%]}\end{array}$ & $\begin{array}{l}-0.15 \\
(0.14) \\
{[59 \%]}\end{array}$ & $\begin{array}{c}0.18 * * \\
(0.07) \\
{[37 \%]}\end{array}$ & $\begin{array}{c}0.09 * * * \\
(0.03) \\
{[41 \%]}\end{array}$ & $\begin{array}{c}0.01 \\
(0.00) \\
{[47 \%]}\end{array}$ \\
\hline
\end{tabular}

Notes: Mean forecast errors and sources of budgetary slippage are expressed in percent of GDP; standard errors (corrected for heteroskedasticity and serial correlation) are reported underneath. The number in square brackets is the percentage of observations below zero. Further, $*=$ significance at the $10 \%$ level; ** = significance at the $5 \%$ level; $* * *=$ significance at the $1 \%$ level. Abbreviations: $B A L=$ Budget balance/GDP; $R E V=$ Revenue/GDP; $E X P=$ Expenditure/GDP; $P E X P=$ primary expenditure/GDP. TE = total error, $\mathrm{BE}=$ base effect, $\mathrm{GE}=$ growth effect, $\mathrm{DE}=$ denominator effect, $\mathrm{RE}=$ residual effect, all in percent of GDP. The sample period is 1999-2008 for Panels (A) and (B), and 1998-2008 for Panel (C). 
Table A.1 in Appendix B (not for publication) repeats all the decompositions when Greece is excluded. Qualitatively the findings are the same as before, although the magnitudes of the averages tend to be smaller. Table A.2 in Appendix B takes account of systematic differences in the variances of the implementation and revision errors between the countries and is based on Generalised Least Square (GLS) regressions of all observations on a constant. The resulting figures are qualitatively and quantitatively essentially the same as before and will not be commented on further.

Panel (A) of Figure 2 depicts the average revision errors in the budget balance over the countries for each year in the sample. In seven out of the eleven years the average revision error is negative. Moreover, the negative averages tend to be much larger in absolute value than the positive averages. Next, Panel (B) of Figure 2 splits the revision errors into their four constituent effects, which are also averages across the countries. The denominator and residual effects are always (virtually) negligible and, hence, the revision errors are always the sum of a base effect and a growth effect. Remarkably, in each of our sample years the average base effect is negative and in a number of years it substantially dominates the growth effect.

Figure 2: Average revision errors in the budget balance across countries

A. Revision errors across countries for each year

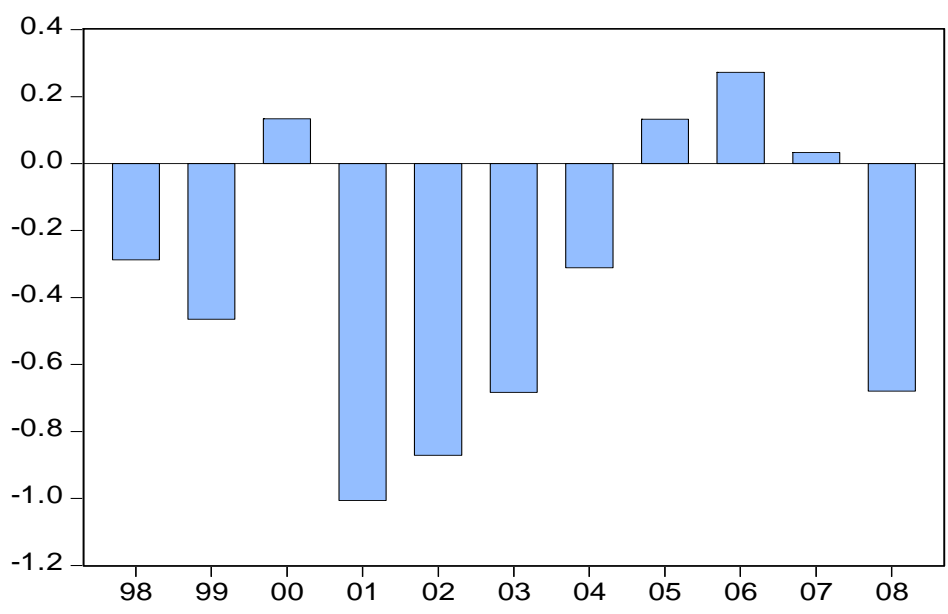

B. Individual effects across countries for each year 


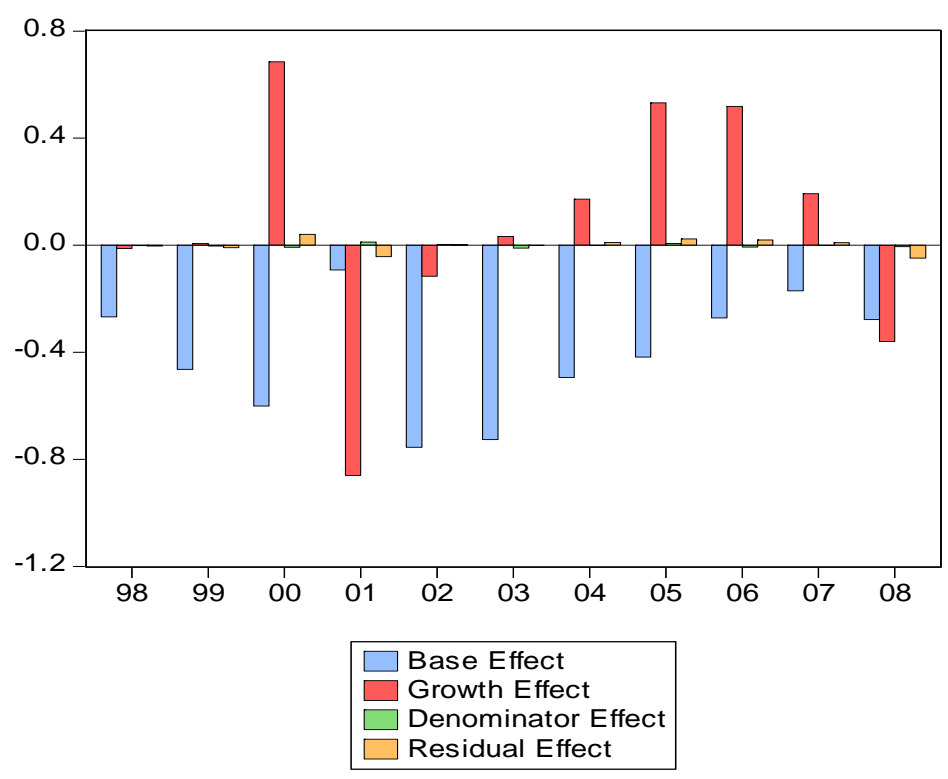

\section{Explaining the revision error and its main components}

The analysis in the previous section clearly showed that the first-release budget balance $B A L_{t}^{t}$ is a biased forecast for the eventual, ex-post figure $B A L_{t}^{f}$. It is of interest to investigate the determinants of the revision error, because this may provide directions for institutional or policy adjustments that improve the quality of first-release data as input for the new budget and for regular budgetary surveillance. In our analysis we pay particular attention to the role of economic variables and political and institutional factors in shaping the revision error. In this section we explore first the determinants of the total revision error $\left(B A L_{t}^{f}-B A L_{t}^{t}\right)$, followed by an analysis of the individual components of the total error. However, we do not analyse the residual effect, because it is only of second order and, given that the denominator effects in revenues and expenditures roughly cancel, we also do not analyse the denominator effect in the balance. Hence, of the terms of the total error we first analyse the base effect $\left(B A L_{t-1}^{f}-B A L_{t-1}^{t}\right)$, followed by an analysis of the growth effect $\left(g_{R E V, t}^{f}-g_{R E V, t}^{t}\right)-\left(g_{E X P, t}^{f}-g_{E X P, t}^{t}\right)$, while controlling for the base effect. Notice that in our analysis, we neglect the scalars in front of these effects - see equation (5). ${ }^{16}$

\footnotetext{
${ }^{16}$ In fact, if we analyse the effects including the scaling factors, we find very similar results.
} 


\subsection{Analysis of the total revision error}

A potentially important economic variable determining $\left(B A L_{t}^{f}-B A L_{t}^{t}\right)$ is the implementation error $\left(B A L_{t}^{t}-B A L_{t}^{t-1}\right)$. The analysis in the previous section suggested that planned balances are on average too optimistic relative to the first-release outcomes, which in turn are on average too optimistic relative to the ex-post outcomes. Hence, both $\left(B A L_{t}^{f}-B A L_{t}^{t}\right)$ and $\left(B A L_{t}^{t}-B A L_{t}^{t-1}\right)$ are on average negative and based on this unconditional correlation we would a priori expect the latter variable to enter the regression for the revision bias with a positive sign. In our regressions for the revision error we shall include the variables $B A L_{t}^{t-1}$ and $B A L_{t}^{t}$ separately, in order to allow for additional flexibility in our specification. Our specification for the revision error in the budget also includes the revision in real growth $G R O W T H_{t}^{f, t} \equiv\left(y r_{t}^{f}-y r_{t}^{t}\right)$, where $y r$ denotes real output growth. Given the generally positive relationship between output and the budget balance, we might expect pessimism about real growth at the first-release stage to translate into pessimism about the balance at this stage and, hence, the real-growth revision error to have a positive effect on the revision error in the budget balance.

We consider also political variables to capture the effect of potential political distortions on the budget revision error. A major type of political distortion concerns "size fragmentation”, which leads to common pool problems and hampers the correction of fiscal excesses. Each fraction of the government wants to increase spending on its own preferred cause, but only partially internalises the cost in terms of higher taxes. This possibility to shift the costs of targeted spending on the general tax payer creates an incentive for overspending, formally illustrated in, for example, Von Hagen and Harden (1994). The original formulation of the common pool problem (Shepsle and Weingast, 1981) features a spending bias, but not necessarily a deficit bias. Subsequent work has also shown how higher deficits can be the outcome of common pool problems, for example, because they give rise to a voracity effect through which positive output shocks result in more than proportionate redistribution (Tornell and Lane, 1999, and Lane, 2003) or wars of attrition (Alesina and Drazen, 1991). Von Hagen (2006) provides a recent overview of the relevant literature. There is no obvious direction in which we can expect more fragmentation to affect the revision error. More fragmentation may lead to stronger pressures for budgetary optimism in order to depict a situation that justifies 
more spending in the coming budget. However, the Finance Ministry, being the producer of the first-release figures, may try to ward off claims for more spending by depicting unduly gloomy figures. As a measure of size fragmentation we use the variable $G O V T Y P E_{t}$, which is an index running from 1 (single party majority government) to 6 (a temporary caretaker government). A second major type of political distortion is the result of "time fragmentation". More frequent changes in government, which shorten the expected tenure of governments, and a larger degree of political polarisation cause more political instability and effectively raise the rate at which governments discount the future. As a result, they internalise to a lesser extent the (reputational) consequences of ex-post deviations of budgetary figures from the first-release figures. In other words, with more "time fragmentation" governments may perceive more leeway to be too optimistic at the first-release stage. Ideally on the basis of these arguments, we should include a measure of the expected government turnover in period $t$. However, since we do not have such a measure we try to capture time fragmentation with the variable $G O V C H A N_{t}$, which measures the number of government changes in year $t$.

One reason for potential over-optimism at the first-release stage is that ahead of an election the government may want to signal its competence at handling the economy (see also Rogoff, 1990). To capture this effect we include an election dummy $E L E C T_{t+1}$, which is one when there is a general election in period $t+1$ and zero otherwise. ${ }^{17}$ However, we will also test whether the contemporaneous election dummy $E L E C T_{t}$ has any effect.

It is also conceivable that revision errors differ with the political colour of the government. We measure this aspect through the variable GOVPARTY ${ }_{t}$, which is an index on the political colour of the cabinet running from 1 (hegemony of right-wing parties) to 5 (hegemony of left-wing parties). Another measure is $G O V G A P_{t}$, which is the ideological gap between new and old cabinet.

We capture the role of institutions with a variety of indices. The "fiscal rules index" $\left(F R I_{t}\right)$ taken from the European Commission measures the presence and strength of numerical fiscal rules. Earlier versions of $F R I_{t}$ have been used by Debrun et al. (2008), for example. The higher the value of $F R I_{t}$, the tighter are fiscal rules. A second index is that for a medium-term budgetary framework $\left(M T B F_{t}\right)$. This index captures the procedures for the preparation, execution and monitoring of multi-annual budget plans. This index should be distinguished from that for fiscal rules, which set numerical targets for important budgetary aggregates. We use two indices to capture fiscal transparency. The first transparency index $T R \_B W_{t}$ is the

\footnotetext{
${ }^{17}$ For refinement in the construction of electoral variables, see for example Mink and de Haan (2005).
} 
index “Audit" taken from Bernoth and Wolf (2008). This index is based on whether governments are externally audited for their finances, the degree of independence of the auditing and the extent to which the obtained information is disseminated. The second index $T_{R}{ }_{-} \mathrm{HSH}_{t}$ is from Hallerberg et al. (2005) and measures the information content of the draft budget. To make the comparison of the sizes of the effects more convenient, we normalise all the indices on a zero-one scale. That is, we assign the minimum value in the sample a value of zero and the maximum value in the sample a value of one and proportionally rescale all the other observations. Table 3 reports the average values of the various (normalised) indices on a country-by-country basis. Notice that Greece always produces a relatively weak score. ${ }^{18}$ It is important to have Greece in our sample, because it adds variation in the quality of our institutional indices, thereby increasing the scope for finding evidence of a systematic link between institutional quality and the size of revision errors.

Table 3: Average normalized values of institutional indices

\begin{tabular}{|c|c|c|c|c|}
\hline & $F R I$ & $M T B F$ & $T R \_B W$ & $T R \_H S H$ \\
\hline Austria & 0.37 & 1.00 & 0.96 & 0.53 \\
\hline Belgium & 0.47 & 0.83 & 0.87 & 0.53 \\
\hline Germany & 0.63 & 0.83 & 0.64 & 0.72 \\
\hline Denmark & 0.82 & 1.00 & 0.83 & 0.49 \\
\hline Greece & 0.00 & 0.00 & 0.00 & 0.38 \\
\hline Spain & 0.61 & 1.00 & 0.40 & 0.62 \\
\hline Finland & 0.70 & 1.00 & 0.89 & 0.91 \\
\hline France & 0.41 & 1.00 & 0.77 & 0.87 \\
\hline Ireland & 0.09 & 0.17 & 0.91 & 0.62 \\
\hline Italy & 0.34 & 0.83 & 0.66 & 0.28 \\
\hline Netherlands & 0.81 & 1.00 & 0.79 & 1.00 \\
\hline Portugal & 0.07 & 0.00 & 0.72 & 0.00 \\
\hline Sweden & 0.75 & 1.00 & 1.00 & 0.72 \\
\hline United Kingdom & 1.00 & 0.83 & 0.62 & 0.62 \\
\hline
\end{tabular}

Table 4 presents our panel estimation results for the total revision error. The baseline specification in Column (1) includes both country-fixed effects and time-fixed effects. The time effects are highly significant. They capture in particular common (across the countries) economic sources of revisions, for example as a result of unforeseen European-wide movements in the business cycle, and common methodological changes in the construction of

\footnotetext{
${ }^{18}$ Results based on the use of $T R \_B W_{t}$ should be interpreted with some care, because Bernoth and Wolf (2008) apply a score of zero for missing answers for Greece in the construction of their index. Obviously, the fact that some answers are missing may be a signal in itself of a lack of transparency.
} 
the figures. ${ }^{19}$ Of the economic variables only the lagged dependent variable is (highly) significant. Its significance may not be too surprising, because revisions of the budget balance reported in the same vintage have a tendency to move into the same direction. Indeed the correlation between $B A L_{t}^{f}$ and $B A L_{t-1}^{f}$ is 0.82 . The planned balance $B A L_{t}^{t-1}$, its first release $B A L_{t}^{t}$ and the real growth revision $G R O W T H_{t}^{f, t}$ are all insignificant. We conjectured that $\left(B A L_{t}^{t}-B A L_{t}^{t-1}\right)$ would exert a positive effect on $\left(B A L_{t}^{f}-B A L_{t}^{t}\right)$. However, the coefficient of $B A L_{t}^{t}$ is negative, while that of $B A L_{t}^{t-1}$ is positive. Replacing these two variables with their difference $\left(B A L_{t}^{t}-B A L_{t}^{t-1}\right)$ yields an insignificant coefficient though, and, hence, this regression is not reported. The sign on the real growth revision is in accordance with our prior that it would exert a positive effect on $\left(B A L_{t}^{f}-B A L_{t}^{t}\right)$. Further, none of our political variables (the election dummy $E L E C T_{t}$, the index of the government type $G O V T Y P E_{t}$ and the political colour variable $\operatorname{GOVPARTY}_{t}$ ) is significant.

Because of the potential feedback effect from the budget balance onto economic growth in Column (2) we instrument the real growth revision with the average real growth revision across the other countries in the sample and the lagged real growth rate. The results remain unchanged and, hence, in the remainder of Table 4 we proceed without using instrumental variables. To take account of the potentially systematic differences in the variances of the revision errors across the countries in our sample, we also estimated our baseline regression using generalised least squares. The results were unaffected, however.

Column (3) estimates the baseline specification excluding Greece. We investigate this case, because Figure 1 revealed Greece as the clearest example of persistent over-optimism at the first-release stage. However, the results are essentially unchanged. Only the (individual) growth revision now becomes significant at the $10 \%$ level.

One may be struck by the failure to find a significant effect of the revision error in real economic growth on the revision error in the budget balance. However, economic growth in substantial parts of the EU is known to be positively correlated and this may also be the case for revision errors in individual countries' growth rates. If this is indeed the case, then at least a substantial part of the potential effect of the growth revision is taken away by including the time effects. Therefore, Column (4) excludes the time effects and the individual real growth revision, while it includes both the weighted (by the respective country's GDP level) average

\footnotetext{
${ }^{19}$ See also Table 7 in De Castro et al. (2011), who explore the role of Eurostat's methodological decisions explicitly.
} 
real growth revision error $\overline{G R O W T H}_{t}^{f, t}$ and the deviation of the individual revision error from its average. The average growth revision error enters with a positive and significant coefficient. Moreover, its magnitude is quite large: a positive growth error revision by one percentage point leads to a positive revision of the budget balance by half a percent of GDP. The remainder of Table 4 reintroduces the time effects, in order to account for all common factors determining revision errors in a given period.

We also estimated a number of other variants on the baseline for which we do not explicitly report the results. First, we experimented by including a dummy variable that took a value of one (zero) when the current first-release deficit was higher (lower) than $3 \%$, the motivation being that governments might try to limit the chances of entering the Excessive Deficit Procedure by limiting the degree to which their first-release deficit violates the 3\% limit. Similarly, we tried a dummy that took a value of unity when the current first-release deficit was between 2 and 3\% of GDP, because in order to avoid the EDP governments might try to "push" their first-release balance to just below 3\%. Both dummies were insignificant, suggesting little if any role for the European level fiscal restrictions at the point where they become binding. Second, we replaced the real growth revision error by including both the nominal growth revision error and the revision error in the GDP deflator. This specification is slightly more flexible. However, the results are unchanged. We also replaced the contemporaneous electoral dummy with the one-period ahead dummy $E L E C T_{t+1}$, the idea being that ahead of elections the government may have an incentive to be over optimistic. However, $E L E C T_{t+1}$ turned out to be insignificant, while the other coefficient estimates were unchanged. Of course, not all elections can be foreseen and $E L E C T_{t+1}$ may be an imperfect measure of the electoral pressure at the moment that the first release data become available. However, we are not able to indicate in the data which elections were unforeseen, while it seems rather unlikely that such a correction would imply a turnaround of the results. Finally, we also explored the relevance of other political variables. In particular, replacing $E L E C T_{t}$

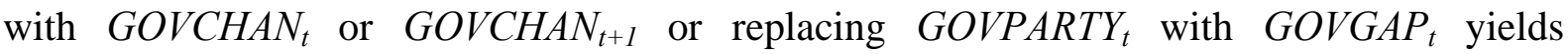
coefficient estimates for these variables that are far from significant.

Column (5) drops the country-fixed effects. As a result, compared with our baseline in Column (1), the coefficient on our lagged dependent variable more than doubles to 0.60 or more and the first-release of the balance becomes significantly negative. The coefficient on the planned balance increases in size, but remains insignificant. The other coefficient estimates remain rather far from significance. In Columns (6) - (9) we include one by one our institutional indices into the regression. Because these variables are either completely time 
invariant or they change relatively little over time, we proceed without the country-fixed effects. Compared with Column (5) the coefficients on the other variables remain essentially unchanged, although the significance of the first-release of the balance tends to strengthen somewhat. We would be reluctant to draw strong conclusions about the precise direction in which fiscal frameworks need to be revised when we find that one or more institutional indicators are significant. In fact, our institutional indicators are proxies intended to capture certain aspects of national fiscal arrangements. Nevertheless, if we find that all or most of our indicators enter with significantly positive coefficient, this would be a clear indication that an increase in institutional quality in its various dimensions is conducive to improving the usefulness of first-release budget figures for surveillance and budgeting purposes. After all, as we have seen, compared with the ex-post figures, first-release budget outcomes tend be overoptimistic. Hence, institutional improvements that reduce the degree of over optimism will be beneficial in this regard. Indeed, we see that all our institutional indicators are estimated with positive coefficients and three out of the four coefficients are significant. Only $T R A_{-} H S H_{t}$ is insignificant. The results suggest that the effects of an institutional improvement are also quantitatively important. For example, an improvement in the fiscal rules index from its minimum to its maximum in-sample value reduces the average degree of optimism in the first-release relative to the ex-post balance outcome by 1.04 percent of GDP. ${ }^{20}$

Of course, the country-fixed effects include all country-specific time-invariant factors affecting the revision errors. Institutional quality along some specific dimension may be only one of them. Hence, an alternative approach is to keep the country-fixed effects in the specification, but to run a regression of the estimates of these effects on our institutional indices. Table A.3 in Appendix B (not for publication) reports the results. Again all indices, except for $T R A_{-} H S H_{t}$ enter with a positive and significant coefficient.

These findings shed some light on some of the conjectures we posed earlier. The outcomes are in line with the hypothesis that more transparency limits the scope for creative accounting at the first-release stage and, hence, that it limits over-optimism at this stage. They are also consistent with the hypothesis that tighter self-imposed national fiscal rules produce smaller revision biases in absolute terms.

\footnotetext{
${ }^{20}$ In fact, if we drop Greece from our sample, the fiscal rules index remains highly significant.
} 
Table 4: Determinants of the total revision error in the budget balance

\begin{tabular}{|c|c|c|c|c|c|c|c|c|c|}
\hline & \multicolumn{9}{|c|}{ Dependent variable: $B A L_{t}^{f}-B A L_{t}^{t}$} \\
\hline & (1) & (2) & (3) & (4) & (5) & (6) & (7) & (8) & (9) \\
\hline$B A L_{t-1}^{f}-B A L_{t-1}^{t-1}$ & $\begin{array}{l}0.30^{* * *} \\
(0.11)\end{array}$ & $\begin{array}{l}0.30^{* * *} \\
(0.11)\end{array}$ & $\begin{array}{l}0.24^{* *} \\
(0.12)\end{array}$ & $\begin{array}{l}0.29^{* * * *} \\
(0.11)\end{array}$ & $\begin{array}{l}0.69^{* * *} \\
(0.10)\end{array}$ & $\begin{array}{l}0.60^{* * *} \\
(0.099)\end{array}$ & $\begin{array}{l}0.64^{* * *} \\
(0.097)\end{array}$ & $\begin{array}{l}0.60^{* * *} \\
(0.095)\end{array}$ & $\begin{array}{c}0.67^{* * *} \\
(0.11)\end{array}$ \\
\hline$B A L_{t}^{t-1}$ & $\begin{array}{l}0.088 \\
(0.15)\end{array}$ & $\begin{array}{l}0.087 \\
(0.15)\end{array}$ & $\begin{array}{l}-0.056 \\
(0.14)\end{array}$ & $\begin{array}{l}-0.14 \\
(0.12)\end{array}$ & $\begin{array}{c}0.17 \\
(0.12)\end{array}$ & $\begin{array}{c}0.13 \\
(0.12)\end{array}$ & $\begin{array}{c}0.19 \\
(0.12)\end{array}$ & $\begin{array}{c}0.18 \\
(0.11)\end{array}$ & $\begin{array}{c}0.16 \\
(0.12)\end{array}$ \\
\hline$B A L_{t}^{t}$ & $\begin{array}{c}-0.12 \\
(0.086)\end{array}$ & $\begin{array}{c}-0.12 \\
(0.087)\end{array}$ & $\begin{array}{c}-0.03 \\
(0.084)\end{array}$ & $\begin{array}{c}-0.02 \\
(0.085)\end{array}$ & $\begin{array}{l}-0.16^{*} \\
(0.092)\end{array}$ & $\begin{array}{l}-0.18^{*} \\
(0.090)\end{array}$ & $\begin{array}{l}-0.19^{* * *} \\
(0.092)\end{array}$ & $\begin{array}{l}-0.19^{* *} \\
(0.087)\end{array}$ & $\begin{array}{l}-0.17^{*} \\
(0.093)\end{array}$ \\
\hline GROWTH $H_{t}^{f, t}$ & $\begin{array}{c}0.15 \\
(0.13)\end{array}$ & $\begin{array}{c}0.10 \\
(0.17)\end{array}$ & $\begin{array}{l}0.21 * \\
(0.13)\end{array}$ & & $\begin{array}{c}0.18 \\
(0.14)\end{array}$ & $\begin{array}{c}0.21 \\
(0.14)\end{array}$ & $\begin{array}{c}0.17 \\
(0.14)\end{array}$ & $\begin{array}{c}0.15 \\
(0.14)\end{array}$ & $\begin{array}{c}0.17 \\
(0.14)\end{array}$ \\
\hline $\begin{array}{l}\text { GROWTH }_{t}^{f, t}- \\
\overline{G R O W T H}_{t}^{f, t}\end{array}$ & & & & $\begin{array}{c}0.09 \\
(0.13)\end{array}$ & & & & & \\
\hline$\overline{\text { GROWTH }}_{t}^{f, t}$ & & & & $\begin{array}{l}0.50^{* *} \\
(0.25)\end{array}$ & & & & & \\
\hline$E L E C T_{t}$ & $\begin{array}{l}-0.13 \\
(0.19)\end{array}$ & $\begin{array}{l}-0.13 \\
(0.19)\end{array}$ & $\begin{array}{l}-0.14 \\
(0.19)\end{array}$ & $\begin{array}{l}-0.09 \\
(0.19)\end{array}$ & $\begin{array}{l}-0.25 \\
(0.21)\end{array}$ & $\begin{array}{l}-0.26 \\
(0.20)\end{array}$ & $\begin{array}{l}-0.26 \\
(0.20)\end{array}$ & $\begin{array}{l}-0.25 \\
(0.20)\end{array}$ & $\begin{array}{l}-0.24 \\
(0.21)\end{array}$ \\
\hline GOVPARTY $_{t}$ & $\begin{array}{l}-0.056 \\
(0.067)\end{array}$ & $\begin{array}{l}-0.052 \\
(0.067)\end{array}$ & $\begin{array}{l}-0.066 \\
(0.067) \\
\end{array}$ & $\begin{array}{l}-0.053 \\
(0.068)\end{array}$ & $\begin{array}{l}-0.012 \\
(0.053)\end{array}$ & $\begin{array}{l}-0.089 \\
(0.058)\end{array}$ & $\begin{array}{l}-0.026 \\
(0.052)\end{array}$ & $\begin{array}{l}0.0032 \\
(0.052)\end{array}$ & $\begin{array}{l}-0.013 \\
(0.053)\end{array}$ \\
\hline$G O V T Y P E_{t}$ & $\begin{array}{l}0.0044 \\
(0.12)\end{array}$ & $\begin{array}{c}-0.0055 \\
(0.12)\end{array}$ & $\begin{array}{l}0.059 \\
(0.12)\end{array}$ & $\begin{array}{l}0.008 \\
(0.11)\end{array}$ & $\begin{array}{c}0.11 \\
(0.086)\end{array}$ & $\begin{array}{c}0.097 \\
(0.081)\end{array}$ & $\begin{array}{c}0.052 \\
(0.085)\end{array}$ & $\begin{array}{c}0.042 \\
(0.085)\end{array}$ & $\begin{array}{c}0.11 \\
(0.086) \\
\end{array}$ \\
\hline$F R I_{t}$ & & & & & & $\begin{array}{l}1.04^{* * *} \\
(0.31)\end{array}$ & & & \\
\hline$M T B F_{t}$ & & & & & & & $\begin{array}{l}0.67^{* *} \\
(0.26)\end{array}$ & & \\
\hline$T R A_{-} B W_{t}$ & & & & & & & & $\begin{array}{l}1.32^{* * *} \\
(0.49)\end{array}$ & \\
\hline$T R A_{-} H S H_{t}$ & & & & & & & & & $\begin{array}{c}0.45 \\
(0.29)\end{array}$ \\
\hline $\begin{array}{l}\text { Country-fixed } \\
\text { effects }\end{array}$ & YES & YES & YES & YES & NO & NO & NO & NO & NO \\
\hline Time-fixed effects & YES & YES & YES & $\mathrm{NO}$ & YES & YES & YES & YES & YES \\
\hline Estimation method & OLS & IV & OLS & OLS & OLS & OLS & OLS & OLS & OLS \\
\hline $\mathrm{R}^{2}$-adjusted & 0.53 & 0.53 & 0.23 & 0.48 & 0.43 & 0.46 & 0.45 & 0.47 & 0.43 \\
\hline DW & 2.06 & 2.04 & 2.09 & 2.12 & 2.25 & 2.20 & 2.23 & 2.18 & 2.21 \\
\hline $\begin{array}{l}\text { Sample period } \\
(t=\ldots)\end{array}$ & $\begin{array}{l}1999- \\
2008\end{array}$ & $\begin{array}{l}1999- \\
2008\end{array}$ & $\begin{array}{l}1999- \\
2008\end{array}$ & $\begin{array}{l}1999- \\
2008\end{array}$ & $\begin{array}{l}1999- \\
2008\end{array}$ & $\begin{array}{l}1999- \\
2008\end{array}$ & $\begin{array}{l}1999- \\
2008\end{array}$ & $\begin{array}{l}1999- \\
2008\end{array}$ & $\begin{array}{l}1999- \\
2008\end{array}$ \\
\hline Country sample & Full & Full & $\begin{array}{c}\text { Greece } \\
\text { excluded }\end{array}$ & Full & Full & Full & Full & Full & Full \\
\hline $\mathrm{N}$ & 139 & 139 & 130 & 139 & 139 & 139 & 139 & 139 & 139 \\
\hline
\end{tabular}

Notes: Estimation as a panel. Standard errors are corrected for heteroskedasticity and serial correlation. Variables referring to the budget balance are in percent of GDP. Further, $*=$ significance at the $10 \%$ level; ** = significance at the $5 \%$ level; ${ }^{* * *}=$ significance at the $1 \%$ level; $\mathrm{N}=$ number of observations. In Column (2), the real growth revision error $G R O W T H_{t}^{f, t}$ is instrumented with the average real growth revision error across the other countries in the sample and the lagged real growth rate. 


\subsection{Analysis of the base effect}

Now we explore the determinants of the base effect $\left(B A L_{t-1}^{f}-B A L_{t-1}^{t}\right)$. Table 5 reports the results for our baseline specification of this regression. The lagged base effect $\left(B A L_{t-2}^{f}-B A L_{t-2}^{t-1}\right)$ enters with a significant and positive coefficient. This is most likely the result of information about the past business cycle becoming more accurate as time passes by. Given the positive correlation of the business cycle in subsequent years, this tends to push $B A L_{t-1}^{f}$ and $B A L_{t-2}^{f}$ into the same direction. The revision of the previous balance $B A L_{t-1}^{t}$ enters with a significant and negative coefficient. In fact, if we were to rewrite the regression equation and add $B A L_{t-1}^{t}$ to both sides of the equation, then this latter variable would enter with a coefficient of 0.89 , which is significantly different from unity, implying a rejection (at the $5 \%$ level) of the hypothesis that the first revision $B A L_{t-1}^{t}$ is an unbiased predictor of the ex-post balance. As in the regressions for the total effect, the political variables do not play any role. If we replace the current electoral dummy $E L E C T_{t}$ with its one period ahead version $E L E C T_{t+1}$ this does not affect the results (not reported in Table 5). ${ }^{21}$

Column (2) drops the country-fixed effects. The coefficient of the lagged base effect and its significance increase substantially. However, the coefficient of the first revision $B A L_{t-1}^{t}$ shrinks and loses its significance. Otherwise, the estimates remain essentially unchanged. Columns (3) - (6) of Table 5 include the institutional indices one by one in regressions without the country-fixed effects. Compared with the regression in Column (2) the coefficient of the first revision becomes significant again in two instances. All indices enter with a positive and significant coefficient, suggesting that better institutions tend to reduce $B A L_{t-1}^{t}$ relative to $B A L_{t-1}^{f}$, thereby making the revision bias on average less negative. As in the case of the total effect, we also regress the fixed effects of the baseline regression in (1) on our institutional indices with qualitatively the same results - see Table A.3 in the Appendix B (not for publication).

\footnotetext{
${ }^{21}$ Note that our baseline regression for the base effect does not include the real growth revision error GROWTH $_{t}^{f, t}$, as this revision error refers to a period $t$ coming after period $t-1$ to which the base effect refers. Indeed, GROWTH f,t turns out to be insignificant in the regression for the base effect.
} 
Table 5: Determinants of the base effect

\begin{tabular}{|c|c|c|c|c|c|c|}
\hline & \multicolumn{6}{|c|}{ Dependent variable: $B A L_{t-1}^{f}-B A L_{t-1}^{t}$} \\
\hline & (1) & (2) & (3) & $(4)$ & (5) & (6) \\
\hline$B A L_{t-2}^{f}-B A L_{t-2}^{t-1}$ & $\begin{array}{c}0.19^{*} \\
(0.11)\end{array}$ & $\begin{array}{l}0.52^{* * *} \\
(0.11)\end{array}$ & $\begin{array}{l}0.47^{* * *} \\
(0.10)\end{array}$ & $\begin{array}{l}0.48^{* * *} \\
(0.10)\end{array}$ & $\begin{array}{l}0.47^{* * *} \\
(0.10)\end{array}$ & $\begin{array}{l}0.49^{* * *} \\
(0.11)\end{array}$ \\
\hline$B A L_{t-1}^{t}$ & $\begin{array}{l}-0.11^{*} \\
(0.063)\end{array}$ & $\begin{array}{l}-0.022 \\
(0.030)\end{array}$ & $\begin{array}{l}-0.063^{*} \\
(0.032)\end{array}$ & $\begin{array}{l}-0.034 \\
(0.029)\end{array}$ & $\begin{array}{l}-0.056^{*} \\
(0.030)\end{array}$ & $\begin{array}{l}-0.048 \\
(0.031)\end{array}$ \\
\hline$E L E C T_{t}$ & $\begin{array}{c}0.21 \\
(0.15)\end{array}$ & $\begin{array}{c}0.16 \\
(0.17)\end{array}$ & $\begin{array}{c}0.16 \\
(0.16)\end{array}$ & $\begin{array}{c}0.15 \\
(0.16) \\
\end{array}$ & $\begin{array}{c}0.17 \\
(0.16)\end{array}$ & $\begin{array}{c}0.17 \\
(0.17)\end{array}$ \\
\hline GOVPARTY $_{t}$ & $\begin{array}{l}-0.039 \\
(0.058)\end{array}$ & $\begin{array}{l}-0.019 \\
(0.046)\end{array}$ & $\begin{array}{l}-0.078 \\
(0.049)\end{array}$ & $\begin{array}{l}-0.029 \\
(0.046)\end{array}$ & $\begin{array}{l}-0.008 \\
(0.046)\end{array}$ & $\begin{array}{l}-0.020 \\
(0.046)\end{array}$ \\
\hline GOVTYPE $E_{t}$ & $\begin{array}{c}-0.022 \\
(0.089)\end{array}$ & $\begin{array}{c}0.031 \\
(0.062)\end{array}$ & $\begin{array}{c}0.016 \\
(0.060)\end{array}$ & $\begin{array}{l}-0.007 \\
(0.062)\end{array}$ & $\begin{array}{l}-0.000 \\
(0.062)\end{array}$ & $\begin{array}{c}0.041 \\
(0.063)\end{array}$ \\
\hline$F R I_{t}$ & & & $\begin{array}{l}0.81^{* * *} \\
(0.27)\end{array}$ & & & \\
\hline$M T B F_{t}$ & & & & $\begin{array}{l}0.47^{* *} \\
(0.23)\end{array}$ & & \\
\hline$T R A_{-} B W_{t}$ & & & & & $\begin{array}{l}0.91^{* *} \\
(0.45)\end{array}$ & \\
\hline$T R A \_H S H_{t}$ & & & & & & $\begin{array}{l}0.59^{* *} \\
(0.24)\end{array}$ \\
\hline $\begin{array}{l}\text { Country-fixed } \\
\text { effects }\end{array}$ & YES & NO & NO & NO & $\mathrm{NO}$ & NO \\
\hline Time-fixed effects & YES & YES & YES & YES & YES & YES \\
\hline Estimation method & OLS & OLS & OLS & OLS & OLS & OLS \\
\hline $\mathrm{R}^{2}$-adjusted & 0.38 & 0.24 & 0.28 & 0.26 & 0.27 & 0.25 \\
\hline DW & 2.12 & 2.30 & 2.26 & 2.28 & 2.25 & 2.25 \\
\hline $\begin{array}{l}\text { Sample period } \\
(t-1=\ldots)\end{array}$ & 1999-2008 & 1999-2008 & 1999-2008 & 1999-2008 & 1999-2008 & 1999-2008 \\
\hline $\mathrm{N}$ & 139 & 139 & 139 & 139 & 139 & 139 \\
\hline
\end{tabular}

Notes: See Table 4.

\subsection{Analysis of the growth effect}

Column (1) of Table 6 reports the results of our baseline regression with the growth effect in the revision error as the dependent variable. Neither the revision of real output growth figure over period $t$, nor any of the political variables is significant. Only the base effect $\left(B A L_{t-1}^{f}-B A L_{t-1}^{t}\right)$ turns out to be significant. We see that a positive revision of the balance in the previous period lowers the growth effect. The intuition is as follows. Consider for instance the revenues side and assume that the revision error $\left(R E V_{t}^{f}-R E V_{t}^{t}\right)$ in revenues is held constant. A fall of $R E V_{t-1}^{f}$ relative to $R E V_{t-1}^{t}$ means that revenues growth between $t-1$ and $t$ has to revised upwards in order to account for the given revision error in revenues. The reasoning is analogous for spending. We have also run a regression in which we added the fiscal plan $B A L_{t}^{t-1}$. However, also this variable turned out to be far from significant, while the 
other estimates remained unchanged. In Column (2) we instrument the output growth surprise. However, the results remain unchanged. Hence, we proceed without using instrumental variables. In Column (3) we exclude the time effects and include the cross-country weighted average revision error in real growth and the deviation of the individual revision error from the average as explanatory variables. The average revision error is positive and highly significant. Moreover, it is large in magnitude. A one-percentage point increase in the average revision error in real growth raises the growth effect in the budget balance by 1.25 percentage points. Column (4) drops the country-fixed effects. The base effect loses its significance, while the type of government GOVTYPE $E_{t}$ now enters with a positive and significant coefficient, suggesting that a more fractionalised government with a smaller majority leads to a larger growth effect, thereby contributing to more over optimism about the balance at the first-release stage.

Columns (5) - (8) add one-by-one our institutional indices to the regression in Column (4). The size of the coefficient of the base effect increases in absolute value and is significant in three of the four cases. However, it always remains less than half the size of the coefficient in the baseline regression in Column (1). Variable GOVTYPE $E_{t}$ loses its significance again, while $E L E C T_{t}$ becomes significantly negative in one instance, a result for which we do not have an obvious interpretation. The other estimates are essentially unaffected. Each of the four institutional indices enters with a positive and significant coefficient, indicating that an increase in institutional quality raises the growth effect in revenues relative to that in expenditures. Better institutional quality reduces over-optimism in the first-release figures, thereby reducing $R E V_{t}^{t}$ or raising $E X P_{t}^{t}$. This produces an increase in the growth effect $\left(g_{R E V, t}^{f}-g_{R E V, t}^{t}\right)-\left(g_{E X P, t}^{f}-g_{E X P, t}^{t}\right)$, thereby reducing the total revision bias in absolute terms. These results are essentially confirmed if we run a regression of the estimated fixed effects from our baseline specification on our institutional indices (see Table A.3 of Appendix B not for publication). All indices come out with a positive coefficient, which is significant in all instances except for $T R A_{-} H S H_{t}$. However, the coefficient on this variable is close to $10 \%$ significance. 
Table 6: Determinants of the growth effect

\begin{tabular}{|c|c|c|c|c|c|c|c|c|}
\hline & \multicolumn{8}{|c|}{ Dependent variable: $\left(g_{R E V, t}^{f}-g_{R E V, t}^{t}\right)-\left(g_{E X P, t}^{f}-g_{E X P, t}^{t}\right)$} \\
\hline & (1) & (2) & (3) & (4) & (5) & (6) & (7) & (8) \\
\hline$B A L_{t-1}^{f}-B A L_{t-1}^{t}$ & $\begin{array}{c}-1.17^{* * *} \\
(0.28)\end{array}$ & $\begin{array}{c}-1.18^{* * *} \\
(0.28)\end{array}$ & $\begin{array}{c}-1.15^{* * *} \\
(0.27)\end{array}$ & $\begin{array}{l}-0.28 \\
(0.27)\end{array}$ & $\begin{array}{l}-0.49^{* *} \\
(0.25)\end{array}$ & $\begin{array}{l}-0.43^{*} \\
(0.25)\end{array}$ & $\begin{array}{l}-0.51^{* *} \\
(0.23)\end{array}$ & $\begin{array}{l}-0.35 \\
(0.28) \\
\end{array}$ \\
\hline$G R O W T H_{t}^{f, t}$ & $\begin{array}{l}0.014 \\
(0.28)\end{array}$ & $\begin{array}{l}-0.11 \\
(0.42)\end{array}$ & & $\begin{array}{c}0.30 \\
(0.32)\end{array}$ & $\begin{array}{c}0.30 \\
(0.31)\end{array}$ & $\begin{array}{c}0.23 \\
(0.31)\end{array}$ & $\begin{array}{c}0.15 \\
(0.28)\end{array}$ & $\begin{array}{c}0.25 \\
(0.32) \\
\end{array}$ \\
\hline $\begin{array}{l}\text { GROWTH } \\
\overline{G R O W T H}_{t}^{f, t}-\end{array}$ & & & $\begin{array}{l}-0.01 \\
(0.29)\end{array}$ & & & & & \\
\hline$\overline{\text { GROWTH }}_{t}^{f, t}$ & & & $\begin{array}{l}1.25^{* *} \\
(0.48)\end{array}$ & & & & & \\
\hline$E L E C T_{t}$ & $\begin{array}{l}-0.45 \\
(0.39) \\
\end{array}$ & $\begin{array}{l}-0.44 \\
(0.39)\end{array}$ & $\begin{array}{l}-0.46 \\
(0.40)\end{array}$ & $\begin{array}{l}-0.65 \\
(0.44)\end{array}$ & $\begin{array}{l}-0.69^{*} \\
(0.41)\end{array}$ & $\begin{array}{l}-0.64 \\
(0.42)\end{array}$ & $\begin{array}{l}-0.59 \\
(0.41)\end{array}$ & $\begin{array}{l}-0.62 \\
(0.43) \\
\end{array}$ \\
\hline GOVPARTY $_{t}$ & $\begin{array}{l}0.010 \\
(0.14)\end{array}$ & $\begin{array}{l}0.018 \\
(0.14)\end{array}$ & $\begin{array}{r}-0.059 \\
(0.14)\end{array}$ & $\begin{array}{l}0.041 \\
(0.12)\end{array}$ & $\begin{array}{l}-0.13 \\
(0.12)\end{array}$ & $\begin{array}{l}0.011 \\
(0.12)\end{array}$ & $\begin{array}{l}0.076 \\
(0.12)\end{array}$ & $\begin{array}{l}0.039 \\
(0.12) \\
\end{array}$ \\
\hline GOVTYPE $E_{t}$ & $\begin{array}{l}-0.25 \\
(0.23) \\
\end{array}$ & $\begin{array}{l}-0.27 \\
(0.23)\end{array}$ & $\begin{array}{l}-0.39 \\
(0.25)\end{array}$ & $\begin{array}{l}0.28^{*} \\
(0.15)\end{array}$ & $\begin{array}{c}0.10 \\
(0.15)\end{array}$ & $\begin{array}{c}0.10 \\
(0.16)\end{array}$ & $\begin{array}{l}0.028 \\
(0.16)\end{array}$ & $\begin{array}{c}0.24 \\
(0.15) \\
\end{array}$ \\
\hline$F R I_{t}$ & & & & & $\begin{array}{l}2.40^{* * * *} \\
(0.70)\end{array}$ & & & \\
\hline$M T B F_{t}$ & & & & & & $\begin{array}{l}1.58^{* *} \\
(0.61)\end{array}$ & & \\
\hline$T R A_{-} B W_{t}$ & & & & & & & $\begin{array}{l}3.16^{* * *} \\
(0.94)\end{array}$ & \\
\hline$T R A_{-} H S H_{t}$ & & & & & & & & $\begin{array}{l}1.27^{* *} \\
(0.60)\end{array}$ \\
\hline Country-fixed effects & YES & YES & YES & NO & NO & NO & NO & NO \\
\hline Time-fixed effects & YES & YES & NO & YES & YES & YES & YES & YES \\
\hline Estimation method & OLS & IV & OLS & OLS & OLS & OLS & OLS & OLS \\
\hline $\mathrm{R}^{2}$-adjusted & 0.32 & 0.31 & 0.21 & 0.15 & 0.22 & 0.19 & 0.23 & 0.16 \\
\hline DW & 2.06 & 2.04 & 2.05 & 2.06 & 2.11 & 2.06 & 2.09 & 2.04 \\
\hline $\begin{array}{l}\text { Sample period } \\
(t=\ldots)\end{array}$ & $\begin{array}{l}1998- \\
2008\end{array}$ & $\begin{array}{l}1998- \\
2008\end{array}$ & $\begin{array}{l}1998- \\
2008\end{array}$ & $\begin{array}{l}1998- \\
2008\end{array}$ & $\begin{array}{l}1998- \\
2008\end{array}$ & $\begin{array}{l}1998- \\
2008\end{array}$ & $\begin{array}{l}1998- \\
2008\end{array}$ & $\begin{array}{l}1998- \\
2008\end{array}$ \\
\hline $\mathrm{N}$ & 145 & 145 & 145 & 145 & 145 & 145 & 145 & 145 \\
\hline
\end{tabular}

Notes: See Table 4.

\section{Conclusions}

There is a growing literature exploring the presence of biases in fiscal plans relative to the fiscal outcomes, which are mostly measured in real time and sometimes ex post. However, with a few exceptions the literature has so far been less concerned with potential biases in first-release fiscal figures as predictors of final figures. The quality of the first-release figures is important, because these figures are an input for the next budget. Moreover, fiscal surveillance is based on these figures. For example, they may provide an indication that fiscal policy is on an unsustainable course and, hence, enable policymakers to undertake timely action to correct fiscal policy. 
The ex-post outcomes are the final figures and are the most accurate measure of the budget, because they are based on the largest information set. They are also the most unbiased measure, because their production is removed furthest from the political process. Deviations of ex-post from first-release fiscal figures may arise for political and strategic reasons. In this paper we have presented a decomposition of these deviations into its various components, the base effect, the growth effect, the denominator effect and, finally, a residual effect. Exploration of the determinants of these individual components may provide us with leads for our analysis of the factors that determine the overall deviations of ex-post from first-release fiscal figures. In turn, this may guide the search for institutional adjustments that improve the first-release figures.

Our findings show that, while fiscal plans are on average too optimistic relative to the first-release outcomes, first-release figures are overly optimistic relative to the ex-post figures. Ministries of Finance control the production of first-release figures and may have an incentive to be over-optimistic at this stage.

For example, better current figures could signal more competence and give more leeway to present an optimistic but seemingly realistic budget for the coming year. In line with our conjectures, we observe that, while most of the over optimism at the planning stage relative to the first-release stage is driven by expenditures, revision errors are mainly caused by over optimism about revenues at the first-release stage. Further, we find that most of the over-optimism at the first-release stage is in the base effect. We also find that an improvement in the quality of institutions, whether measured by the tightness of national fiscal rules, the medium-term budgetary framework or the degree of budgetary transparency, reduces the degree of optimism at the first-release stage and makes first-release figures more informative about the eventual outcomes. This is in line with our earlier conjecture that more transparency reduces the leeway for massaging budgetary figures at the first-release stage and, hence, that it limits over-optimism at this stage. It is also in line with the hypothesis that tighter selfimposed, national fiscal rules have the same effect.

Our results on the role of tight fiscal rules and medium-term national budgetary frameworks for the quality of first-release figures support the European Commission's (2010) proposal to specify minimum requirements for national budgetary frameworks. Also our findings on the role of enhanced transparency support the European Commission (2010), which proposes that "All the operations of extra-budgetary funds and bodies shall be integrated into the regular budgetary process" and "For all sub-sectors of general government, Member States shall publish information on contingent liabilities with potentially large 
impacts on public budgets, ...”. Moreover, amendment proposals by the European Parliament (2010, p. 19-20, and p. 35) provide a more general legal basis for the role of national budgetary frameworks in improving the implementation of fiscal policy at the national level. Its proposals on national ownership require that euro area countries incorporate the objectives of the Stability and Growth Pact into national law and elaborate national budgetary frameworks that ensure compliance with these objectives. These amendments also stress the role of independent statistics, national fiscal policy rules or institutes, and realistic and cautious macro-economic and budgetary forecasts. An agreement is planned for the June 2011 summit of the European Council.

While the changes proposed by the European Commission (2010) serve a wider purpose than improving only the accuracy of first-release macro- and fiscal data, a more direct way of achieving the latter may be to transfer the responsibility for producing these data to an independent institution. ${ }^{22}$ However, to achieve this, both political and practical obstacles may have to be overcome. The main practical complication is that the Ministry of Finance always needs to be relied upon to provide relevant real-time data.

Our analysis finally points to some recommendations regarding the conduct of fiscal surveillance. First, policymakers should focus less on slippages year by year and more on systematic patterns in errors and components of those errors. With first-release and ex-post data becoming available over longer horizons, the scope for such an approach is increasing. Second, by comparing fiscal data across countries, one can extract more accurate signals whether implementation and revision errors can be justified or not. Third, with SGP surveillance based on first-release figures, there is an incentive for governments to bias these figures, which makes them less useful for fiscal surveillance. As our results suggest, to ameliorate this trade-off, it is important that surveillance at the European level be combined with enhanced fiscal transparency at the national level. In particular, judgment of first-release figures should be on a sufficiently comprehensive basis taking proper account of stock-flow adjustments and the risks associated with off-balance items. Finally, as our results showed, revision errors in the budget balance may mask substantial and partially offsetting revision errors in revenues and spending. Therefore, it is important for fiscal surveillance to also focus on the individual components of the budget balance.

\footnotetext{
${ }^{22}$ Frankel (2011) in his study of Chilean fiscal policy over the past decade argues in favour of supplementing budget rules with panels of independent fiscal experts that provide official forecasts of the output gap, for example.
} 


\section{References}

Abbas, S.A., Hasanov, F., Mauro, P. and J. Park (2011). The Performance of Large Fiscal Adjustment Plans in the European Union - A Cross-Country Statistical Analysis, Mimeo, IMF.

Alesina, A. and A. Drazen (1991). Why are Stabilizations Delayed? A Political Economy Model, American Economic Review 81, 1170-88.

Armingeon et al. (2010). Comparative Political Dataset, No. I and III, http://www.ipw.unibe.ch/content/team/klaus_armingeon/comparative_political_data_sets/i ndex_ger.html .

Balassone, F., Franco, D. and S. Zotteri (2006). EMU Fiscal Indicators: a Misleading Compass? Empirica 33, 63-87.

Balassone, F., Franco, D. and S. Zotteri (2007). The Reliability of EMU Fiscal Indicators: Risks and Safeguards, Temi di Discussione, No. 633, Banca d'Italia.

Beetsma, R. and M. Giuliodori (2010). Fiscal Adjustment to Cyclical Developments in the OECD: An Empirical Analysis Based on Real-Time Data, Oxford Economic Papers 62, 3, 419-441.

Beetsma, R., Giuliodori, M. and P. Wierts (2009). Planning to Cheat: EU Fiscal Policy in Real Time, Economic Policy 24, 60, 753-804.

Beetsma, R., Giuliodori, M., Walschot, M. and P. Wierts (2010). Fifty Years of Fiscal Planning and Implementation in the Netherlands, CEPR Discussion Paper, No.7969.

Bernoth, K. and G. Wolff (2006). Fool the Markets? Creative Accounting, Fiscal Transparency and Sovereign Risk Premia, DNB Working Paper, No.103.

Bernoth, K. and G. Wolff (2008). Fool the Markets? Creative Accounting, Fiscal Transparency and Sovereign Risk Premia, Scottish Journal of Political Economy, 55, 4, 465-487.

Bernoth, K., Hughes-Hallett, A.J., and J. Lewis (2008). Did Fiscal Policymakers Know What They Were Doing? Re-assessing Fiscal Policy with Real-Time Data, CEPR Discussion Paper, No.6758.

Brück, T. and A. Stephan (2006). Do Eurozone Countries Cheat with their Budget Deficit Forecasts? Kyklos 59, 3-15.

Cimadomo, J. (2007). Fiscal Policy in Real Time, CEPII Working Paper, No. 2007-10.

Debrun, X., L. Moulin, A. Turrini, J. Ayuso-Calsals, and M. Kumar (2008). Tied to the Mast? The Role of National Fiscal Rules in the European Union, Economic Policy, 23, 298 362, April.

De Castro, F., Pérez, J.J. and M. Rodríguez (2011). Fiscal Data Revisions in Europe, mimeo, Banco de España / European Central Bank.

European Commission (2007), Public Finances in EMU - 2007, European Economy, No.3, Directorate-General for Economic and Financial Affairs, Brussels.

European Commission (2010), http://ec.europa.eu/economy_finance/articles/eu_economic_situation/pdf/com2010_523e n.pdf.

European Parliament (2010/0280), DRAFT REPORT on the Proposal for a Regulation of the European Parliament and of the Council Amending Regulation (EC) No 1466/97 on the Strengthening of the Surveillance of Budgetary Positions and the Surveillance and Coordination of Economic Policies, Committee on Economic and Monetary Affairs, Rapporteur: C. Wortmann-Kool.

Forni, L. and S. Momigliano (2004). Cyclical Sensitivity of Fiscal Policies Based on RealTime Data, Applied Economics Quarterly 50, 3, 299-326. 
Frankel, J. (2011). A Solution to Fiscal Procyclicality: The Structural Budget Institutions Pioneered by Chile, NBER Working Paper, No. 16945.

Gordo, M.L. and J.N. Nogueira Martins (2007). How Reliable are the Statistics for the Stability and Growth Pact? European Commission Economic Papers, No. 273.

Hallerberg, M., Strauch, R. and J. von Hagen (2005). Fiscal Rules in the European Union 1991-2001: Updating the Von Hagen Fiscal Index, Mimeo.

Heinemann, F. (2006). Planning or Propaganda? An Evaluation of Germany’s Medium-Term Budgetary Planning, Finanzarchiv 62, 4, 551-78.

Holm-Hadulla, F., Hauptmeier, S. and P. Rother (2011). The Impact of Numerical Expenditure Rules on Budgetary Discipline over the Cycle, Applied Economics, forthcoming.

Lane, P.R. (2003). The Cyclical Behaviour of Fiscal Policy: Evidence from the OECD, Journal of Public Economics 87, 2661-2675.

Lewis, J. (2009). Fiscal Policy in Central and Eastern Europe with Real-Time Data: Cyclicality, Inertia and the Role of EU Accession, Working Paper, No.214/2009, De Nederlandsche Bank.

Marinheiro, C. (2008). The Stability and Growth Pact, Fiscal Policy Institutions and Stabilization in Europe, International Economics and Economic Policy 5, 1, 189-207.

Milesi-Feretti, G.M. (2003). Good, Bad or Ugly? On the Effects of Fiscal Rules with Creative Accounting, Journal of Public Economics 88, 377-394.

Mink, M. and J. De Haan (2005). Has the Stability and Growth Pact Impeded Political Budget Cycles in the European Union? CESifo Working Paper, No. 1532.

Moulin, L. and P. Wierts (2006). How Credible are Multiannual Budgetary Plans in the EU? in Franco, D., Marino, M. and S. Momigliano (eds.), Fiscal Indicators, Banca d'Italia, 983-1005.

OECD (2008). Budget Practices and Procedures Survey, http://webnet4.oecd.org/budgeting/Budgeting.aspx.

Pina, A. (2009). Elusive Counter-Cyclicality and Deliberate Opportunism? Fiscal Policy from Plans to Final Outcomes. Bank of Portugal Working Paper, No. 6, April.

Pina, A. and N. Venes (2011). The Political Economy of EDP Fiscal Forecasts: An Empirical Assessment, European Journal of Political Economy, forthcoming.

Rogoff, K. (1990). Equilibrium Political Budget Cycles, American Economic Review 80, 1, 21-36.

Shepsle, K.A. and B.R. Weingast (1981). Political Preferences for the Pork Barrel: A Generalization, American Journal of Political Science 25, 96-111.

Strauch, R., Hallerberg, M. and J. von Hagen (2004). Budgetary Forecasts in Europe - the Track Record of Stability and Convergence Programmes, ECB Working Paper, No. 307.

Tornell, A. and P.R. Lane (1999). The Voracity Effect, American Economic Review 89, $22-$ 46.

Von Hagen, J. (2006). Political Economy of Fiscal Institutions, in Weingast, B.A. and D.T. Wittman (eds.), The Oxford Handbook of Political Economy, Oxford University Press, Oxford.

Von Hagen, J. (2010). Sticking to Fiscal Plans: The Role of Fiscal Institutions, Public Choice 144, 487-503.

Von Hagen, J. and I. Harden (1994). Budget Processes and Commitment to Fiscal Discipline, European Economic Review 39, 771-779.

Von Hagen, J., Hughes Hallett, A. and R. Strauch (2002). Budgetary Consolidation in Europe: Quality, Economic Conditions, and Persistence, Journal of the Japanese and International Economics 16, 512-535. 


\section{Appendix A: The data}

Sources and description of political variables:

The political variables are from the Comparative Political Data Set (CPDS), numbers I and III, constructed by Armingeon et al. (2010), supplemented by self-constructed figures for the year 2009 (CPDS-I covers 1960-2007, while CPDS-III covers 1990-2008).

ELECT The dummy is 1, if there is a general election in the year, and 0, otherwise.

GOVCHAN Number of government changes in the year. Termination of government due to (a) elections, (b) resignation of the Prime Minister, (c) dissension within government, (d) lack of parliamentary support, or (e) intervention by the Head of State.

GOVPARTY Cabinet composition (Schmidt-Index) on a scale from 1 to 5 , where 1 is hegemony of right-wing (and centre) parties, 2 is dominance of right-wing (and centre) parties, 3 is balance of power between left and right, 4 is dominance of social-democratic and other left parties and 5 is hegemony of social-democratic and other left parties.

GOVTYPE Type of government ranging from 1 to 6 , where 1 is single party majority government, 2 is minimal winning coalition, 3 is surplus coalition, 4 is single party minority government, 5 is multi party minority government and 6 is caretaker government (temporary).

GOVGAP Ideological gap between new and old cabinet $(G O V G A P=\triangle G O V P A R T Y)$.

Sources and description of institutional variables:

FRI

In its database about fiscal governance in EU Member States, the European Commission calculates a fiscal rule index $(F R I)$ per country, ${ }^{23}$ which combines the strength and coverage of all rules in force. Those rules may apply to the various government sectors (general, central, regional, local and social security). Strength is determined on the basis of five criteria: (1) the statutory or legal base of the rule (with a constitutional rule where there is

\footnotetext{
23 See http://ec.europa.eu/economy_finance/db_indicators/fiscal_governance/index_en.htm.
} 
no margin for adjusting objectives achieving the highest score); (2) the nature of the body in charge of monitoring the rule (the highest score assigned in the case of an independent authority or the national parliament); (3) the nature of the body in charge of enforcing the rule (again, the highest score for an independent authority or the national parliament); (4) the enforcement mechanism (highest score in the case of automatic corrections and sanctions in case of non-compliance); and (5) the degree of media visibility. The strength score of each rule is weighed by the share of general government finances covered. Finally, the weighted scores are aggregated over all rules in place, while if more than one rule applies to the same general government sub-sector the weights of all these rules except the strongest are halved.

MTBF European Commission (2007, p.162-163) computes the index of a national medium-term budgetary framework $(M T B F)$ on the basis of five criteria: (1) the existence of such a framework (with the highest score for a framework that covers the entire government); (2) connectedness between the multi-annual budgetary targets and the preparation of the annual budget (with the highest score for a framework that cannot be altered as time passes); (3) involvement of the national parliament (the highest score is when a vote is required); (4) existence of coordination mechanisms prior to setting the medium-term budgetary targets (with the highest score for ex-ante coordination among all levels of general government); and (5) monitoring and enforcement (the highest score for regular monitoring and well-defined actions in response to deviations from plans).

TR_BW This is the index "Audit” taken from Bernoth and Wolff (2008). It is based on the answers to an OECD and World Bank survey conducted in 2003. It is higher for countries in which governments are externally audited for their finances, when the degree of independence of the auditing is higher and the obtained information is more widely disseminated. Details on the survey questions are found in Bernoth and Wolff (2006).

\section{TR_HSH}

This index is taken from Hallerberg et al. (2005). It measures the information content and transparency of the draft budget and is further based on an assessment of transparency by government officials, the importance of special funds in the draft budget, whether government loans are included, whether it is linked to the national accounts and whether it consists of one document. 


\section{Appendix B: Additional results (NOT for publication)}

Table A.1. Decomposition of errors in the budget and its components excluding Greece

\begin{tabular}{|c|c|c|c|c|c|}
\hline \multicolumn{6}{|c|}{ (A) Implementation errors based on first-release data minus plans } \\
\hline & TE & BE & GE & DE & RE \\
\hline$B A L$ & $\begin{array}{l}-0.10 \\
(0.10) \\
{[50 \%]}\end{array}$ & $\begin{array}{c}0.16 * * * \\
(0.05) \\
{[35 \%]}\end{array}$ & $\begin{array}{c}-0.25 * * * \\
(0.09) \\
{[58 \%]}\end{array}$ & $\begin{array}{c}0.00 \\
(0.00) \\
{[41 \%]}\end{array}$ & $\begin{array}{c}-0.01 * * \\
(0.01) \\
{[59 \%]}\end{array}$ \\
\hline$R E V$ & $\begin{array}{c}0.13 \\
(0.12) \\
{[46 \%]}\end{array}$ & $\begin{array}{c}0.05 \\
(0.10) \\
{[42 \%]}\end{array}$ & $\begin{array}{l}-0.05 \\
(0.08) \\
{[53 \%]}\end{array}$ & $\begin{array}{c}-0.12 * * \\
(0.05) \\
{[55 \%]}\end{array}$ & $\begin{array}{c}0.00 \\
(0.00) \\
{[47 \%]}\end{array}$ \\
\hline EXP & $\begin{array}{c}0.23 * * \\
(0.11) \\
{[42 \%]}\end{array}$ & $\begin{array}{c}-0.11 \\
(0.10) \\
{[56 \%]}\end{array}$ & $\begin{array}{c}0.20 * * * \\
(0.05) \\
{[36 \%]}\end{array}$ & $\begin{array}{c}-0.13^{* *} \\
(0.05) \\
{[55 \%]}\end{array}$ & $\begin{array}{c}0.02 * * * \\
(0.004) \\
{[34 \%]}\end{array}$ \\
\hline$P E X P$ & $\begin{array}{c}0.29 * * * \\
(0.11) \\
{[37 \%]}\end{array}$ & $\begin{array}{l}-0.07 \\
(0.09) \\
{[53 \%]}\end{array}$ & $\begin{array}{c}0.22 * * * \\
(0.05) \\
{[30 \%]}\end{array}$ & $\begin{array}{c}-0.13 * * \\
(0.05) \\
{[56 \%]}\end{array}$ & $\begin{array}{c}0.02 * * * \\
(0.00) \\
{[30 \%]}\end{array}$ \\
\hline \multicolumn{6}{|c|}{ (B) Implementation errors based on ex-post data minus plans } \\
\hline & TE & BE & GE & DE & RE \\
\hline$B A L$ & $\begin{array}{l}-0.21 \\
(0.15) \\
{[55 \%]}\end{array}$ & $\begin{array}{l}-0.13 \\
(0.09) \\
{[54 \%]}\end{array}$ & $\begin{array}{c}-0.08 \\
(0.13) \\
{[54 \%]}\end{array}$ & $\begin{array}{c}0.00 \\
(0.00) \\
{[52 \%]}\end{array}$ & $\begin{array}{l}-0.01 \\
(0.01) \\
{[52 \%]}\end{array}$ \\
\hline REV & $\begin{array}{l}-0.28 \\
(0.19) \\
{[58 \%]}\end{array}$ & $\begin{array}{c}-0.52 * * * \\
(0.17) \\
{[66 \%]}\end{array}$ & $\begin{array}{c}0.23 * * \\
(0.10) \\
{[37 \%]}\end{array}$ & $\begin{array}{c}0.01 \\
(0.07) \\
{[50 \%]}\end{array}$ & $\begin{array}{l}0.01^{*} \\
(0.00) \\
{[38 \%]}\end{array}$ \\
\hline EXP & $\begin{array}{l}-0.07 \\
(0.18) \\
{[52 \%]}\end{array}$ & $\begin{array}{c}-0.40 * * \\
(0.15) \\
{[62 \%]}\end{array}$ & $\begin{array}{c}0.30 * * * \\
(0.08) \\
{[33 \%]}\end{array}$ & $\begin{array}{c}0.00 \\
(0.07) \\
{[50 \%]}\end{array}$ & $\begin{array}{c}0.02 * * * \\
(0.01) \\
{[40 \%]}\end{array}$ \\
\hline PEXP & $\begin{array}{c}0.15 \\
(0.18) \\
{[44 \%]}\end{array}$ & $\begin{array}{l}-0.22 \\
(0.15) \\
{[58 \%]}\end{array}$ & $\begin{array}{c}0.35 * * * \\
(0.09) \\
{[32 \%]}\end{array}$ & $\begin{array}{c}0.00 \\
(0.06) \\
{[50 \%]}\end{array}$ & $\begin{array}{c}0.02 * * * \\
(0.01) \\
{[38 \%]}\end{array}$ \\
\hline \multicolumn{6}{|c|}{ (C) Revision errors based on ex-post data minus first-release data } \\
\hline & TE & BE & GE & $\mathbf{D E}$ & $\mathbf{R E}$ \\
\hline$B A L$ & $\begin{array}{l}-0.13 \\
(0.08) \\
{[56 \%]}\end{array}$ & $\begin{array}{c}-0.29 * * * \\
(0.06) \\
{[69 \%]}\end{array}$ & $\begin{array}{l}0.15 * \\
(0.08) \\
{[44 \%]}\end{array}$ & $\begin{array}{l}-0.00 \\
(0.00) \\
{[54 \%]}\end{array}$ & $\begin{array}{c}0.00 \\
(0.00) \\
{[45 \%]}\end{array}$ \\
\hline$R E V$ & $\begin{array}{c}-0.34 * * \\
(0.16) \\
{[64 \%]}\end{array}$ & $\begin{array}{c}-0.51^{* * *} \\
(0.13) \\
{[73 \%]}\end{array}$ & $\begin{array}{c}0.26 * * * \\
(0.06) \\
{[33 \%]}\end{array}$ & $\begin{array}{c}0.11 * * * \\
(0.03) \\
{[39 \%]}\end{array}$ & $\begin{array}{c}0.01 * * \\
(0.00) \\
{[37 \%]}\end{array}$ \\
\hline$E X P$ & $\begin{array}{l}-0.21 \\
(0.15) \\
{[58 \%]}\end{array}$ & $\begin{array}{l}-0.22 \\
(0.13) \\
{[59 \%]}\end{array}$ & $\begin{array}{c}0.11 \\
(0.08) \\
{[42 \%]}\end{array}$ & $\begin{array}{c}0.12 * * * \\
(0.03) \\
{[39 \%]}\end{array}$ & $\begin{array}{c}0.00 \\
(0.00) \\
{[47 \%]}\end{array}$ \\
\hline$P E X P$ & $\begin{array}{c}0.01 \\
(0.14) \\
{[53 \%]}\end{array}$ & $\begin{array}{c}-0.04 \\
(0.13) \\
{[58 \%]}\end{array}$ & $\begin{array}{l}0.14^{*} \\
(0.07) \\
{[38 \%]}\end{array}$ & $\begin{array}{c}0.11 * * * \\
(0.03) \\
{[39 \%]}\end{array}$ & $\begin{array}{c}0.00 \\
(0.00) \\
{[49 \%]}\end{array}$ \\
\hline
\end{tabular}

Notes: Mean forecast errors and sources of budgetary slippage are expressed in percent of GDP; standard errors (corrected for heteroskedasticity and serial correlation) are reported underneath. The number in square brackets is the percentage of observations below zero. Further, $*=$ significance at the $10 \%$ level; ** = significance at the $5 \%$ level; $* * *=$ significance at the $1 \%$ level. Abbreviations: $B A L=$ Budget balance/GDP; $R E V=$ Revenue/GDP; $E X P=$ Expenditure/GDP; $P E X P=$ primary expenditure/GDP. $\mathrm{TE}=$ total error, $\mathrm{BE}=$ base effect, $\mathrm{GE}=$ growth effect, $\mathrm{DE}=$ denominator effect, $\mathrm{RE}$ = residual effect, all in percent of GDP. The sample period is 1999-2008 for Panels (A) and (B), and 1998-2008 for Panel (C). 
Table A.2. Decomposition of errors in the budget and its components with GLS

\begin{tabular}{|c|c|c|c|c|c|}
\hline \multicolumn{6}{|c|}{ (A) Implementation errors based on first-release data minus plans } \\
\hline & TE & BE & GE & DE & RE \\
\hline$B A L$ & $\begin{array}{l}-0.10 \\
(0.07) \\
{[51 \%]}\end{array}$ & $\begin{array}{c}0.13 * * * \\
(0.03) \\
{[39 \%]}\end{array}$ & $\begin{array}{c}-0.24 * * * \\
(0.06) \\
{[59 \%]}\end{array}$ & $\begin{array}{c}0.00 \\
(0.00) \\
{[43 \%]}\end{array}$ & $\begin{array}{c}-0.01 * * * \\
(0.01) \\
{[60 \%]}\end{array}$ \\
\hline$R E V$ & $\begin{array}{c}0.01 \\
(0.07) \\
{[48 \%]}\end{array}$ & $\begin{array}{l}-0.05 \\
(0.06) \\
{[45 \%]}\end{array}$ & $\begin{array}{l}-0.05 \\
(0.06) \\
{[53 \%]}\end{array}$ & $\begin{array}{l}-0.05^{*} \\
(0.03) \\
{[53 \%]}\end{array}$ & $\begin{array}{c}0.00 \\
(0.00) \\
{[47 \%]}\end{array}$ \\
\hline EXP & $\begin{array}{c}0.21 * * \\
(0.09) \\
{[43 \%]}\end{array}$ & $\begin{array}{c}-0.13^{* *} \\
(0.06) \\
{[55 \%]}\end{array}$ & $\begin{array}{c}0.19 * * * \\
(0.04) \\
{[36 \%]}\end{array}$ & $\begin{array}{l}-0.05 \\
(0.03) \\
{[53 \%]}\end{array}$ & $\begin{array}{c}0.01 * * * \\
(0.002) \\
{[34 \%]}\end{array}$ \\
\hline$P E X P$ & $\begin{array}{c}0.27 * * * \\
(0.09) \\
{[38 \%]}\end{array}$ & $\begin{array}{l}-0.05 \\
(0.06) \\
{[52 \%]}\end{array}$ & $\begin{array}{c}0.18 * * * \\
(0.04) \\
{[31 \%]}\end{array}$ & $\begin{array}{l}-0.05^{*} \\
(0.03) \\
{[54 \%]}\end{array}$ & $\begin{array}{c}0.01 * * * \\
(0.00) \\
{[31 \%]}\end{array}$ \\
\hline \multicolumn{6}{|c|}{ (B) Implementation errors based on ex-post data minus plans } \\
\hline & TE & BE & GE & DE & RE \\
\hline$B A L$ & $\begin{array}{c}-0.37 * * * \\
(0.12) \\
{[58 \%]}\end{array}$ & $\begin{array}{l}-0.11^{*} \\
(0.06) \\
{[57 \%]}\end{array}$ & $\begin{array}{c}-0.23 * * \\
(0.10) \\
{[56 \%]}\end{array}$ & $\begin{array}{l}-0.00 \\
(0.00) \\
{[53 \%]}\end{array}$ & $\begin{array}{c}-0.01 * * \\
(0.004) \\
{[55 \%]}\end{array}$ \\
\hline$R E V$ & $\begin{array}{c}-0.63 * * * \\
(0.10) \\
{[61 \%]}\end{array}$ & $\begin{array}{c}-0.72 * * * \\
(0.09) \\
{[67 \%]}\end{array}$ & $\begin{array}{c}0.14^{* *} \\
(0.07) \\
{[39 \%]}\end{array}$ & $\begin{array}{l}-0.01 \\
(0.05) \\
{[49 \%]}\end{array}$ & $\begin{array}{c}0.01 * * \\
(0.00) \\
{[41 \%]}\end{array}$ \\
\hline EXP & $\begin{array}{l}-0.16 \\
(0.12) \\
{[52 \%]}\end{array}$ & $\begin{array}{c}-0.60 * * * \\
(0.09) \\
{[62 \%]}\end{array}$ & $\begin{array}{c}0.37 * * * \\
(0.04) \\
{[33 \%]}\end{array}$ & $\begin{array}{l}-0.00 \\
(0.05) \\
{[49 \%]}\end{array}$ & $\begin{array}{c}0.02 * * * \\
(0.00) \\
{[39 \%]}\end{array}$ \\
\hline$P E X P$ & $\begin{array}{c}0.08 \\
(0.11) \\
{[44 \%]}\end{array}$ & $\begin{array}{c}-0.43^{* * *} \\
(0.09) \\
{[58 \%]}\end{array}$ & $\begin{array}{c}0.42 * * * \\
(0.05) \\
{[31 \%]}\end{array}$ & $\begin{array}{l}-0.00 \\
(0.05) \\
{[49 \%]}\end{array}$ & $\begin{array}{c}0.02 * * * \\
(0.00) \\
{[37 \%]}\end{array}$ \\
\hline \multicolumn{6}{|c|}{ (C) Revision errors based on ex-post data minus first-release data } \\
\hline & TE & $\mathbf{B E}$ & GE & DE & RE \\
\hline$B A L$ & $\begin{array}{c}-0.15 * * \\
(0.06) \\
{[59 \%]}\end{array}$ & $\begin{array}{c}-0.26 * * * \\
(0.05) \\
{[71 \%]}\end{array}$ & $\begin{array}{c}0.04 \\
(0.06) \\
{[48 \%]}\end{array}$ & $\begin{array}{l}-0.00 * \\
(0.00) \\
{[53 \%]}\end{array}$ & $\begin{array}{c}0.00 \\
(0.00) \\
{[48 \%]}\end{array}$ \\
\hline$R E V$ & $\begin{array}{c}-0.56 * * * \\
(0.08) \\
{[66 \%]}\end{array}$ & $\begin{array}{c}-0.60 * * * \\
(0.06) \\
{[74 \%]}\end{array}$ & $\begin{array}{c}0.22 * * * \\
(0.04) \\
{[34 \%]}\end{array}$ & $\begin{array}{c}0.10 * * * \\
(0.03) \\
{[41 \%]}\end{array}$ & $\begin{array}{c}0.00 * * * \\
(0.00) \\
{[38 \%]}\end{array}$ \\
\hline EXP & $\begin{array}{c}-0.42 * * * \\
(0.09) \\
{[58 \%]}\end{array}$ & $\begin{array}{c}-0.42^{* * *} \\
(0.08) \\
{[61 \%]}\end{array}$ & $\begin{array}{c}0.17 * * * \\
(0.04) \\
{[41 \%]}\end{array}$ & $\begin{array}{c}0.11 * * * \\
(0.03) \\
{[41 \%]}\end{array}$ & $\begin{array}{c}0.00 \\
(0.00) \\
{[45 \%]}\end{array}$ \\
\hline$P E X P$ & $\begin{array}{c}-0.21 * * \\
(0.10) \\
{[53 \%]}\end{array}$ & $\begin{array}{c}-0.28 * * * \\
(0.08) \\
{[59 \%]}\end{array}$ & $\begin{array}{c}0.17 * * * \\
(0.03) \\
{[37 \%]}\end{array}$ & $\begin{array}{c}0.10 * * * \\
(0.03) \\
{[41 \%]}\end{array}$ & $\begin{array}{c}0.00 \\
(0.00) \\
{[47 \%]}\end{array}$ \\
\hline
\end{tabular}

Notes: Generalized Least Square (GLS) estimation. Mean forecast errors and sources of budgetary slippage are expressed in percent of GDP; standard errors (corrected for heteroskedasticity and serial correlation) are reported underneath. The number in square brackets is the percentage of observations below zero. Further, * = significance at the $10 \%$ level; $* *=$ significance at the $5 \%$ level; $* * *=$ significance at the $1 \%$ level. Abbreviations: $B A L=$ Budget balance/GDP; $R E V=$ Revenue/GDP; $E X P=$ Expenditure/GDP; $P E X P=$ primary expenditure/GDP. TE = total error, $\mathrm{BE}=$ base effect, $\mathrm{GE}=$ growth effect, $\mathrm{DE}=$ denominator effect, $\mathrm{RE}=$ residual effect, all in percent of GDP. The sample period is 1999-2008 for Panels (A) and (B), and 1998-2008 for Panel (C). 
Table A.3: Relationship between institutional indices and country-fixed effects

\begin{tabular}{|l|c|c|c|c|}
\hline & \multicolumn{4}{|c|}{ Dependent variable: estimated country-fixed effects } \\
\hline & $F R I$ & $M T B F$ & $T R \_B W$ & $T R \_H S H$ \\
\hline Total revision error & $1.51^{* * *}$ & $1.15^{* *}$ & $1.98^{* * *}$ & 1.09 \\
& $(0.54)$ & $(0.45)$ & $(0.59)$ & $(0.76)$ \\
\hline Base effect & $1.13^{* *}$ & $0.85^{* *}$ & $1.50^{* * *}$ & $1.14^{*}$ \\
& $(0.46)$ & $(0.38)$ & $(0.51)$ & $(0.58)$ \\
\hline Growth effect & $2.96^{* *}$ & $2.50^{* *}$ & $4.49^{* * *}$ & 2.37 \\
& $(1.24)$ & $(0.97)$ & $(1.22)$ & $(1.64)$ \\
\hline
\end{tabular}

Notes: Entries report the coefficient of the institutional index (averaged over time) in a linear OLS regression of the estimated country-fixed effects from the baseline regression on a constant and the average institutional index over time for each country. Estimates of the constant are not reported. Standard errors are reported in brackets underneath the coefficient estimate. The number of observations is in all cases 14. 